\title{
Social inequalities in female mortality by region and by selected causes of death, England and Wales, 2001-03
}

Ann Langford, Brian Johnson and Alaa Al-Hamad

Office for National Statistics

This article reports on social inequalities in female mortality by region and cause of death for women aged 25-59 years in England and Wales in the period 2001-03. It is the first official compilation of detailed mortality statistics for women based on the National Statistics Socioeconomic Classification (NS-SEC). It is part of a series of articles measuring inequalities in adult mortality.

The results demonstrate a strong socio-economic effect on the mortality of women in all regions. This pattern remained consistent between regions.

There were marked differences in the socio-economic gradient by cause. Mortality rates for women in the least and most advantaged NS-SEC classes were similar for breast cancer. In contrast, compared to women in the most advantaged class, mortality rates were three times as high for the least advantaged women for lung cancer and cerebrovascular disease, around five times as high for ischaemic heart disease and all digestive diseases, and six times as high for respiratory diseases.

\section{Introduction}

This article describes social inequalities in adult female mortality rates for selected causes of death and across the Government Office Regions of England, and Wales. It is the fifth in a series of articles reporting mortality using the final version of the National Statistics Socio-economic Classification (NS-SEC). The first three articles covered social inequalities by NS-SEC for men, ${ }^{1}$ by cause of death, ${ }^{2}$ and by Government Office Region. ${ }^{3}$ The fourth article examined inequalities for women in all-cause mortality, ${ }^{4}$ and presented results for two classifications, one based on a woman's own occupation, and another on a 'combined' classification based on the most advantaged NS-SEC class of the woman or her husband.

This study focuses on women aged 25-59 in the period 2001-03, and uses the 'combined' NS-SEC classification to analyse mortality rates by region and selected causes of death.

\section{Background}

There is a long history of the study of health inequalities by socio-economic classification in England and Wales. The influential Black report ${ }^{5}$ showed that there had been a striking lack of improvement in the health experience of the less advantaged social classes up to the 1970s. The Acheson Report ${ }^{6}$ in 1998 highlighted widening differences between the expectation of life of the most advantaged and most disadvantaged groups in society. The Government strategy Tackling Health Inequalities: A programme for action ${ }^{7}$ aspired to 'address the inequalities that are found across different geographical areas, between genders... and between different social and economic groups'. Four years later, however, the 2007 Status Report on the Programme for Action ${ }^{8}$ reported that 'the gap has not narrowed for life expectancy in disadvantaged areas; indeed, the gap has widened, particularly for women.' 
The interest in health inequalities has led to a large volume of literature on the analysis of mortality by socio-economic classification ${ }^{9,10,11}$ but relatively little on mortality in women. This is due, in part, to a number of well-known difficulties inherent in any analysis of female mortality by a classification based on occupation. ${ }^{12}$ There are conceptual difficulties because many women have weaker ties to the labour market than men, which reduces the potential relevance of occupation-based indicators of social class. There are also practical difficulties, since the occupation of a substantial minority of women is inadequately described at death registration and, in many cases, is not recorded at all.

The previous article in this series ${ }^{4}$ examined two methods of classification for women. One was based on the woman's own occupation, and the other on a 'combined' measure which also took into account the husband's classification, where available and if reflecting more advantage than the woman's own occupational class. The concept behind the latter classification is similar to the 'dominance' approach first suggested by Erikson ${ }^{13}$ who maintained that the life-chances of individuals in a family unit are more likely to be aligned with those of the most advantaged individual in that unit. The idea was summarised as follows: 'A secretary who is married to an executive may have life chances closer to those of executives than to those of other secretaries. ${ }^{14}$ The previous article in this series ${ }^{4}$ found that the 'combined' measure was a better discriminator of female mortality, with the mortality rate among those assigned to the least advantaged class 2.6 times that of those in the most advantaged class.

Previous authors ${ }^{11,15}$ have studied inequalities in the mortality of women by cause using the Registrar General's Social Class (RGSC). ${ }^{15}$ Others have studied inequalities in the mortality of women by region and cause in the early $1990 \mathrm{~s}^{16}$ and covering the period of this study ${ }^{17}$ but both these studies analysed by deprivation of area of residence rather than individual socioeconomic characteristics. All have found evidence of inequalities that vary by cause and region. However this article is the first to present an analysis of the mortality of women by selected causes of death and region using the new measure of social class - the NS-SEC - which replaced the RGSC in 2001.

\section{Methods}

In this article the measure of social class used is the National Statistics Socioeconomic Classification (NS-SEC), which is described below, along with the definition of the regions and the selected causes analysed. The sources of data, calculation methods and outcomes are also described in this section.

\section{The classification of women by the National Statistics Socio-economic Classification (NS-SEC)}

The National Statistics Socio-economic Classification (NS-SEC) was developed in order to replace the Registrar General's Social Class, which had been criticised as lacking a coherent theoretical basis and becoming increasingly irrelevant to the changing patterns of industry and employment in modern economies. ${ }^{18}$

The conceptual basis of the NS-SEC is the structure of employment relations operating in modern developed economies. ${ }^{19}$ Occupations are differentiated in terms of reward mechanisms, promotion prospects, autonomy and job security. The most advantaged NSSEC classes (for example higher managerial and professional occupations), typically exhibit personalised reward structures, have good opportunities for advancement, have relatively high levels of autonomy within the job, and are relatively secure. These attributes tend to be reversed for the most disadvantaged classes (for example routine occupations). Box One shows the NS-SEC analytical class breakdowns used in this analysis, and provides examples of the occupations included in each class.

Further information on the rationale, derivation and application of the NS-SEC is available on the Office for National Statistics (ONS) website. $^{20}$

This analysis uses the 'combined' classification method, whereby a non-married woman is assigned an NS-SEC class on the basis of her own occupation and employment status, and a married woman is assigned the most advantaged NS-SEC class of either herself or her husband.

\section{Regions and selected causes of death}

This article focuses on mortality in the Government Office Regions of England and in Wales. Government Office Regions are the largest level statistical sub-divisions in England (Box Two). Wales is not sub-divided in this analysis. For convenience, use of the term 'region' throughout this article includes Wales.

Further information can be found in the guide to UK geography on the ONS website. ${ }^{21}$

\section{Box one}

\section{National Statistics Socio-economic Classification - analytic classes}

Analytic class

$1 \quad$ Higher managerial and professional occupations

2 Lower managerial and professional occupations

3 Intermediate occupations

$4 \quad$ Small employers and own account workers

$5 \quad$ Lower supervisory and technical occupations

6 Semi-routine occupations

7 Routine occupations Other
Examples of occupations included

Directors and chief executives of major organisations, civil engineers, medical practitioners, IT strategy and planning professionals, legal professionals, architects, senior officials in national and local government Teachers in primary and secondary schools, quantity surveyors, public service administrative professionals, social workers, nurses, IT technicians

Graphic designers, medical and dental technicians, Civil Service administrative officers and local government clerical officers, counter clerks, school and company secretaries

Hairdressing and beauty salon proprietors, shopkeepers, dispensing opticians in private practice, farmers, selfemployed decorators

Bakers and flour confectioners, catering supervisor, head waitress, postal supervisor, sales assistant supervising others

Retail assistants, catering assistants, clothing cutters, dressmaker, traffic wardens, veterinary nurses and assistants, shelf fillers

Hairdressing employees, floral arrangers, sewing machinists, bar staff, cleaners and domestics

Full-time students, never worked, long-term unemployed, inadequately described, not classifiable for other reasons

Source: NS-SEC User Manual, Office for National Statistics 


\section{Box two}

\section{The Government Office Regions of England}

\author{
North East (NE) \\ North West (NW) \\ Yorkshire and The Humber (YH) \\ East Midlands (EM) \\ West Midlands (WM) \\ East of England (E) \\ London (L) \\ South East (SE) \\ South West (SW)
}

The causes of death examined in this article are listed in Box Three, along with the number and percentage of all deaths represented in the study population. These causes of death account for approximately 80 per cent of all deaths among women aged 25-59. Causes of death were grouped to ensure sufficiently large numbers for robust statistical analysis when broken down by region and NS-SEC class. Thus the mortality rates reported in this article are for all deaths, four major groups of causes and four specific causes of death. Deaths were coded to the tenth revision of the International Classification of Diseases (ICD). ${ }^{22}$

\section{Box three}

\section{Causes of death to women 25-59 included in the analysis}

\begin{tabular}{|c|c|c|c|}
\hline Cause of death & ICD-10 codes & $\begin{array}{l}\text { Number } \\
\text { of deaths }\end{array}$ & $\begin{array}{l}\text { Percentage } \\
\text { of deaths }\end{array}$ \\
\hline All causes & $\begin{array}{l}\text { A00-R99, } \\
\text { V00-Y89 }\end{array}$ & 65,276 & 100 \\
\hline $\begin{array}{l}\text { All cancers } \\
\text { Trachea, bronchus and lung } \\
\text { Breast cancer }\end{array}$ & $\begin{array}{l}\mathrm{C} 00-\mathrm{C} 97 \\
\mathrm{C} 33-\mathrm{C} 34 \\
\mathrm{C} 50\end{array}$ & $\begin{array}{r}31,639 \\
4,607 \\
9,313\end{array}$ & $\begin{array}{r}48 \\
7 \\
14\end{array}$ \\
\hline $\begin{array}{l}\text { All circulatory diseases } \\
\text { Ischemic heart disease } \\
\text { Cerebrovascular disease }\end{array}$ & $\begin{array}{l}100-199 \\
120-125 \\
160-169\end{array}$ & $\begin{array}{r}11,505 \\
4,616 \\
3,559\end{array}$ & $\begin{array}{r}18 \\
7 \\
5\end{array}$ \\
\hline All respiratory diseases & J00-J99 & 3,794 & 6 \\
\hline All digestive diseases & K00-K93 & 5,322 & 8 \\
\hline
\end{tabular}

\section{Sources of data}

\section{Numerators}

The routine collection of data at death registration provided the number of deaths in each age-group for each NS-SEC class in each region for the period 2001-03. These data were used as the basis of numerators for the mortality rates.

The numbers of deaths were subject to two adjustments. The first reapportioned some deaths from NS-SEC analytical classes 3 to class 2. In the first study of this series ${ }^{1}$ examination of the ONS Longitudinal Study (LS), a one per cent sample of linked census and death records, revealed that a number of men had been allocated at death registration to NS-SEC class 3 on the basis that they had no supervisory duties. Examination of their 2001 linked Census records revealed, however, that they had in fact been supervisors in 2001, and thus were more appropriately assigned to NS-SEC class 2. A similar phenomenon was observed on examination of the records of women in the ONS Longitudinal Study, and appropriate adjustment factors were calculated to correct for this bias. ${ }^{4}$

The second adjustment was to correct for the under-reporting of the occupation of women at death. The previous article ${ }^{4}$ reported that for 19 per cent of deaths insufficient occupational details were available to allow classification by 'combined' NS-SEC. In a sample of 158 women who were 'unclassified at death', the NS-SEC classification could be determined by reference to their census records. The distribution of this sample (Table 1) was used to reallocate the unclassified women across NS-SEC classes in this study

Appendix A contains Tables A1 and A2, showing the numbers of deaths after these adjustments, by five-year age-band and 'combined' NS-SEC, for region and selected causes respectively.

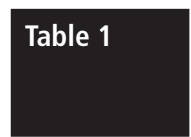

England and Wales
NS-SEC class ${ }^{1}$ at Census for those female members of the LS who died 2001-05 and were not classified or inadequately described at death

\begin{tabular}{|c|c|c|c|c|c|c|c|c|c|}
\hline \multicolumn{7}{|c|}{ England and Wales } & \multicolumn{3}{|c|}{ Numbers and percentages } \\
\hline & \multicolumn{9}{|c|}{ NS-SEC analytic class } \\
\hline & 1 & 2 & 3 & 4 & 5 & 6 & 7 & $\begin{array}{l}\text { Other } \\
\text { and } \\
\text { FTS }^{2}\end{array}$ & Total \\
\hline Numbers & 6 & 12 & 19 & 7 & 14 & 32 & 22 & 46 & 158 \\
\hline Percentages & 4 & 8 & 12 & 4 & 9 & 20 & 14 & 29 & 100 \\
\hline
\end{tabular}

1 NS-SEC assigned by the 'combined' method whereby if married the most advantaged class of either the woman or her husband is used to represent the woman's classification.

2 Other and FTS includes never worked, long-term unemployed, inadequately described, not classifiable for other reasons and full-time students.

Source: ONS Longitudinal Study

\section{Denominators}

All denominators were based on the 'optimised population estimates' for mortality analysis presented in the previous article. ${ }^{4}$ To obtain regional denominators, for each age group and NS-SEC combination, the percentage distribution across the regions was calculated from 2001 Census data. The resulting percentages were applied to the optimised population estimates in order to obtain an estimate of person-years at risk by five-year age group and NS-SEC for each region.

Appendix A also contains Table A3, showing the resulting population estimates by region.

\section{Outcome measures}

Mortality rates per 100,000 person years, age-standardised to the European standard population, were calculated for each NS-SEC class in each Government Office Region, and for each selected cause of death. As in previous articles in this series ${ }^{1,2,3,4}$ the ratio between the mortality rates of the least and most advantaged NS-SEC classes is also presented. For convenience, this mortality rate ratio is referred to as the 'socio-economic gradient'.

\section{Results}

\section{Mortality by region}

Age-standardised mortality rates by NS-SEC for Government Office Regions and Wales are presented in Table 2. Shaded areas denote rates that are statistically significantly different from the corresponding rate for England and Wales as a whole. The results are illustrated graphically in Figure 1. Figure 2 displays the socio-economic gradient, that is the ratio of mortality rates of those assigned to routine occupations relative to those assigned to higher managerial and professional occupations, for each region.

The highest gradients are in London and the North West, where women classified to routine occupations have a mortality rate 3.0 

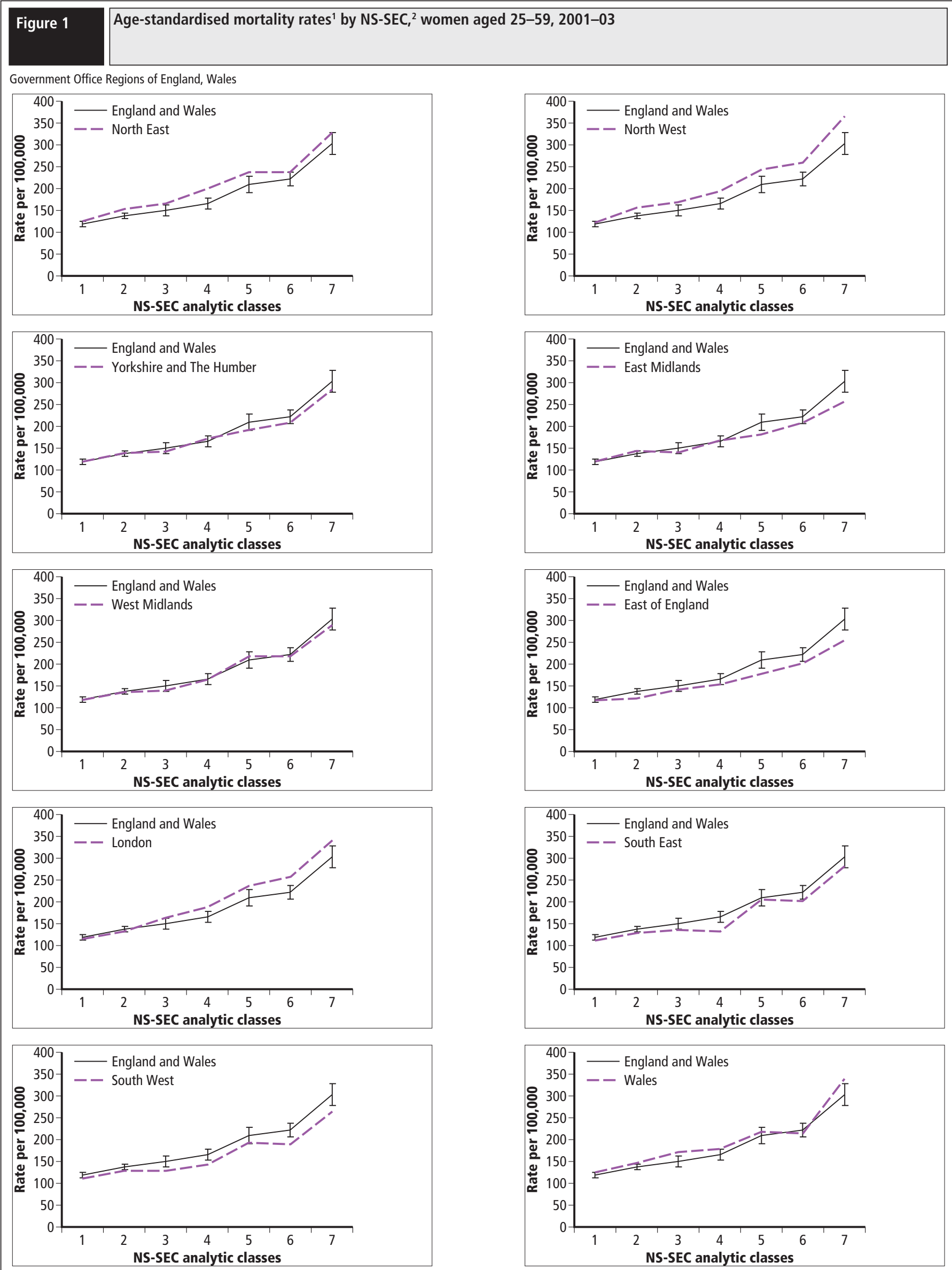

1 Directly age-standardised rate using the European standard population.

2 NS-SEC assigned by the 'combined' method whereby if married the most advantaged class of either the woman or her husband is used to represent the woman's classification. Adjustments for the under-recording of death have been applied as described in Methods 


\section{Table 2}

Age-standardised mortality rates ${ }^{1}$ by NS-SEC, ${ }^{2}$ women aged 25-59, 2001-03

\begin{tabular}{|c|c|c|c|c|c|c|c|c|}
\hline \multicolumn{7}{|c|}{ Government Office Regions of England, Wales } & \multicolumn{2}{|c|}{ Rates per 100,00} \\
\hline & \multicolumn{4}{|c|}{ NS-SEC analytic class } & \multirow[b]{2}{*}{5} & \multirow[b]{2}{*}{6} & \multirow[b]{2}{*}{7} & \multirow[b]{2}{*}{$\begin{array}{l}\text { Socio- } \\
\text { economic } \\
\text { gradient }\end{array}$} \\
\hline & 1 & 2 & 3 & 4 & & & & \\
\hline North East & 126 & $\begin{array}{r}153 \\
\text { H }\end{array}$ & 167 & $\begin{array}{r}201 \\
\mathrm{H}\end{array}$ & 237 & 237 & 329 & 2.6 \\
\hline North West & 123 & $\begin{array}{r}156 \\
\text { H }\end{array}$ & 169 & $\begin{array}{r}195 \\
\mathrm{H}\end{array}$ & $\begin{array}{r}244 \\
\mathrm{H}\end{array}$ & $\begin{array}{r}260 \\
\mathrm{H}\end{array}$ & $\begin{array}{r}367 \\
\mathrm{H}\end{array}$ & 3.0 \\
\hline Yorkshire and The Humber & 118 & 138 & 141 & 171 & 192 & 208 & 285 & 2.4 \\
\hline East Midlands & 120 & 142 & 141 & 169 & $\begin{array}{r}182 \\
\mathrm{~L}\end{array}$ & 209 & $\begin{array}{r}258 \\
\text { L }\end{array}$ & 2.1 \\
\hline West Midlands & 116 & 137 & 138 & 164 & 217 & 216 & 290 & 2.5 \\
\hline East of England & 118 & $\begin{array}{r}123 \\
\mathrm{~L}\end{array}$ & 141 & 152 & $\begin{array}{r}179 \\
\text { L }\end{array}$ & 202 & $\begin{array}{r}253 \\
\text { L }\end{array}$ & 2.1 \\
\hline London & 114 & 133 & 164 & 187 & 235 & $\begin{array}{r}258 \\
\mathrm{H}\end{array}$ & 341 & 3.0 \\
\hline South East & 111 & $\begin{array}{r}128 \\
\mathrm{~L}\end{array}$ & 137 & $\begin{array}{r}133 \\
\mathrm{~L}\end{array}$ & 204 & 201 & 282 & 2.5 \\
\hline South West & 112 & $\begin{array}{r}127 \\
\text { L }\end{array}$ & $\begin{array}{r}130 \\
\text { L }\end{array}$ & $\begin{array}{r}145 \\
\mathrm{~L}\end{array}$ & 193 & $\begin{array}{r}189 \\
\text { L }\end{array}$ & 264 & 2.4 \\
\hline Wales & 127 & 148 & 170 & 179 & 218 & 215 & 340 & 2.7 \\
\hline England & 116 & 136 & 147 & 164 & 209 & 221 & 298 & 2.6 \\
\hline England and Wales & 118 & 137 & 149 & 165 & 210 & 221 & 302 & 2.6 \\
\hline
\end{tabular}

1 Directly standardised rate using the European standard population.

2 NS-SEC assigned by the 'combined' method whereby if married the most advantaged

class of either the woman or her husband is used to represent the womans classification. Adjustments for the under-recording of death have been applied as described in Methods.

3 Ratio of mortality rates of NS-SEC class 7 to the mortality rate of NS-SEC class 1.

Rate is statistically significantly higher than that for England and Wales. Rate is statistically significantly lower than that for England and Wales.

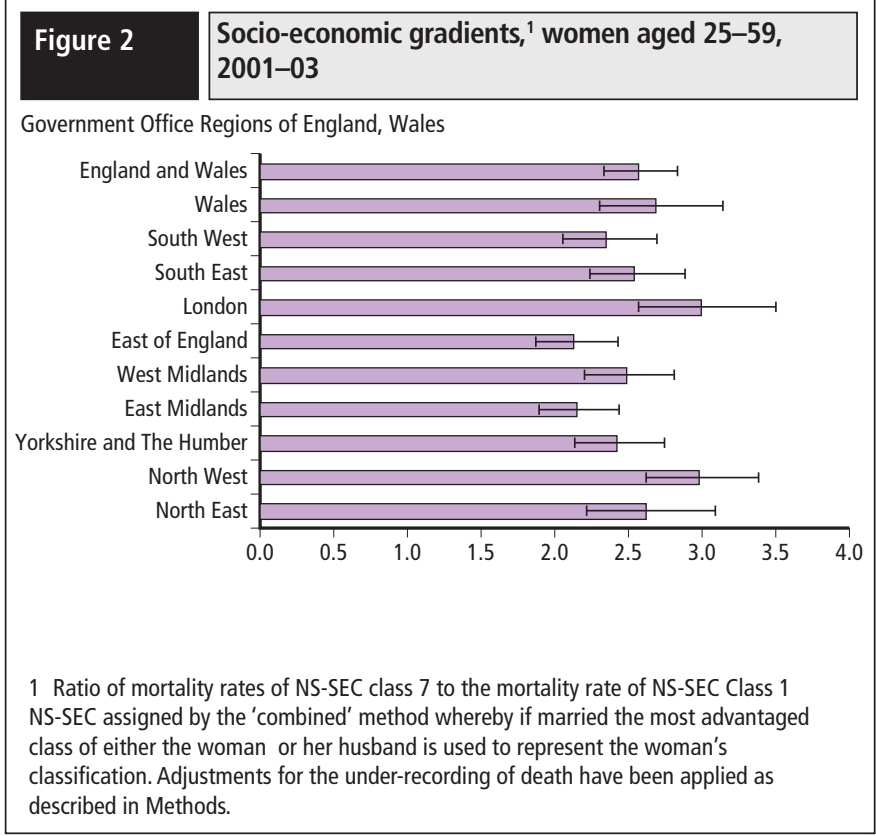

\section{Figure 3 Age-standardised mortality rates ${ }^{1}$ by NS-SEC} analytic class, ${ }^{2}$ women aged 25-59, 2001-03

Government Office Regions of England, Wales

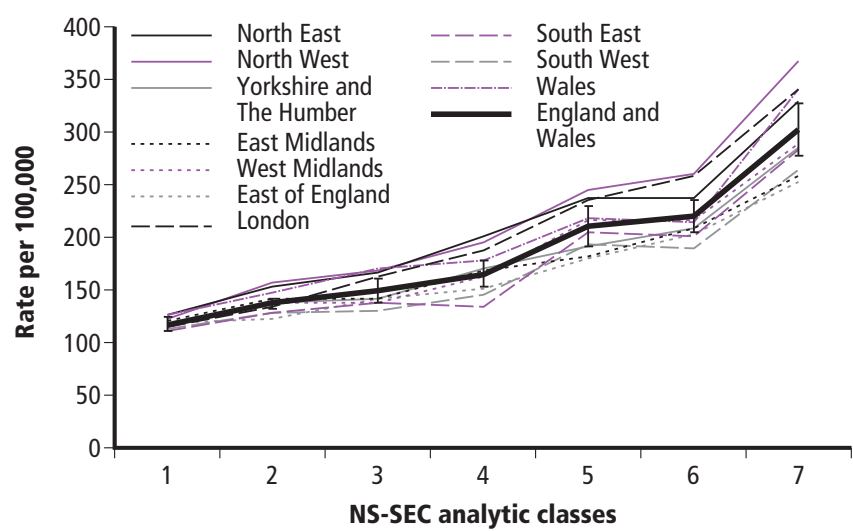

1 Directly age-standardised using European standard population.

2 NS-SEC assigned by the 'combined' method whereby if married the most advantaged class of either the woman or her husband is used to represent the woman's classification. Adjustments for the under-recording of death have been applied as described in Methods.

times that of women classified to higher managerial and professional occupations. This gradient is not however statistically significantly higher than the gradient for England and Wales as a whole (2.6). The lowest gradients are in the East of England and the East Midlands (2.1), and these gradients are statistically significantly lower than those for England and Wales.

Figure 3 demonstrates that there is relatively little difference in mortality rates between regions for the more advantaged classes, but more substantial differences for the more disadvantaged classes.

In detail, the results show that age-adjusted mortality rates in the North West for most NS-SEC classes are statistically significantly higher than the corresponding rates for England and Wales. In both the North West and the North East, mortality rates for each NS-SEC class are consistently higher than the corresponding rate for England and Wales.

Most mortality rates in the South West are statistically significantly lower than the corresponding NS-SEC class rates for England and Wales. In both the South West and the South East, mortality rates for each NS-SEC class are consistently lower than the corresponding rate for England and Wales.

\section{Mortality by selected causes}

\section{Cancer}

Table 3 presents the age-standardised rates by NS-SEC for all cancers; trachea, bronchus and lung cancer, and breast cancer. The results are displayed in Figure 4.

The mortality rates for all cancers displayed a distinct socio-economic pattern. The socio-economic gradient, that is the ratio of mortality rate of NS-SEC class 7 to NS-SEC class 1, was approximately 1.5. This implies that women in the least advantaged class had a mortality rate approximately oneand-a-half times that of women in the most advantaged class. 


\begin{tabular}{|c|c|c|c|c|c|c|c|c|c|}
\hline \multirow[b]{2}{*}{ NS-SEC analytic class } & \multicolumn{3}{|c|}{ All cancers } & \multicolumn{3}{|c|}{ Trachea, bronchus and lung } & \multicolumn{3}{|c|}{ Breast cancer } \\
\hline & Rate & $\begin{array}{c}\text { Lower 95\% } \\
\text { confidence } \\
\text { interval }\end{array}$ & $\begin{array}{c}\text { Upper } 95 \% \\
\text { confidence } \\
\text { interval }\end{array}$ & Rate & $\begin{array}{l}\text { Lower } 95 \% \\
\text { confidence } \\
\text { interval }\end{array}$ & $\begin{array}{c}\text { Upper } 95 \% \\
\text { confidence } \\
\text { interval }\end{array}$ & Rate & $\begin{array}{l}\text { Lower } 95 \% \\
\text { confidence } \\
\text { interval }\end{array}$ & $\begin{array}{c}\text { Upper } 95 \% \\
\text { confidence } \\
\text { interval }\end{array}$ \\
\hline 1 Higher managerial and professional & 75 & 72 & 78 & 7 & 6 & 8 & 26 & 25 & 28 \\
\hline 2 Lower managerial and professional & 77 & 75 & 80 & 9 & 9 & 10 & 25 & 24 & 26 \\
\hline 3 Intermediate & 73 & 69 & 77 & 9 & 8 & 10 & 22 & 21 & 24 \\
\hline 4 Small employers and own account workers & 87 & 82 & 91 & 14 & 12 & 15 & 23 & 22 & 25 \\
\hline 5 Lower supervisory and technical & 102 & 96 & 108 & 17 & 15 & 19 & 27 & 25 & 29 \\
\hline 6 Semi-routine & 90 & 86 & 95 & 16 & 15 & 18 & 24 & 22 & 25 \\
\hline 7 Routine & 116 & 108 & 123 & 23 & 21 & 25 & 29 & 26 & 31 \\
\hline Ratio of classes 7:1 & 1.5 & 1.4 & 1.7 & 3.3 & 2.9 & 3.7 & 1.1 & 1.0 & 1.2 \\
\hline
\end{tabular}

1 Directly age-standardised using European standard population.

2 NS-SEC assigned by the 'combined' method whereby if married the most advantaged class of either the woman or her husband is used to represent the woman's classification. Adjustments for the under-recording of death have been applied as described in Methods.

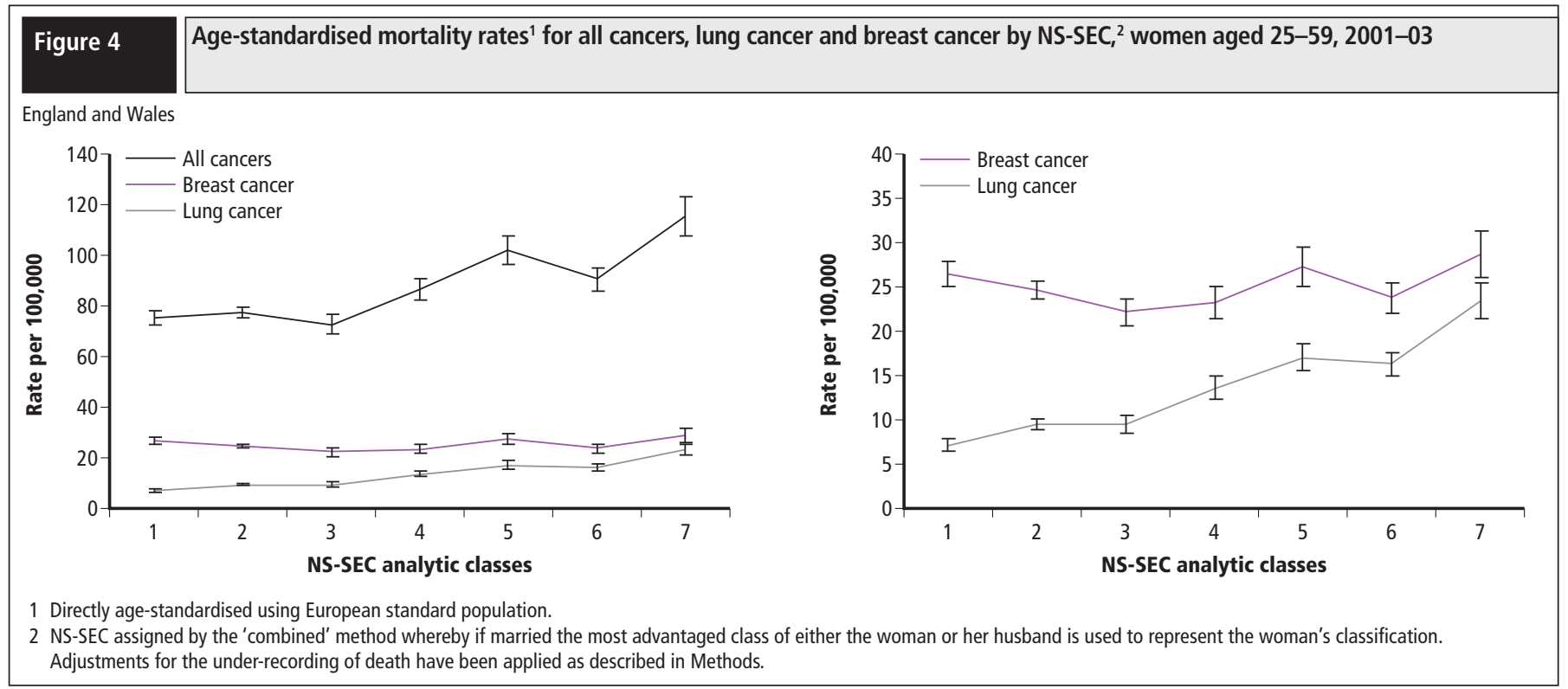

The mortality rates for breast cancer, however, were fairly consistent over the socio-economic classes, with a gradient of only 1.1. The rate for the most advantaged class was not statistically significantly different from that of the least advantaged class. The pattern for lung cancer was quite different. Most classes had a statistically significantly higher mortality rate than the previous class, and mortality rates for women in the least advantaged class were more than three times that of women in the most advantaged class.

\section{Circulatory diseases}

Table 4 presents the age-standardised rates by NS-SEC for all circulatory diseases, and for ischaemic heart disease and cerebrovascular diseases separately. The results are displayed in Figure 5.

The mortality rates for all circulatory diseases displayed a more pronounced socio-economic pattern than those for cancer. Most classes had significantly higher mortality rates than the previous class. The exception was between NS-SEC classes 5 and 6 (lower supervisory and technical, and semi-routine). The mortality rate for NS-SEC class 7 (routine workers) was particularly high. The socio-economic gradient, that is the ratio of mortality rate of NS-SEC class 1 to NS-SEC class 7, was approximately 4.2. This implies that women in the least advantaged class had a mortality rate approximately four times that of women in the most advantaged class.
The socio-economic pattern was very similar for ischaemic heart disease. Women in the least advantaged class had a mortality rate 5.3 times that of women in the most advantaged class.

The socio-economic pattern for cerebrovascular disease was rather different to that of ischaemic heart disease.(Figure 5) The differences in mortality rates between adjacent classes were more consistent and the mortality rate for NS-SEC class 7 was not markedly higher. The socioeconomic gradient was still high at 3.4 , but was statistically significantly lower than the gradient for all circulatory diseases.

\section{Respiratory and digestive diseases}

The results for these two groups of diseases are shown in Table 5 and displayed in Figure 6. The socio-economic pattern of mortality rates was similar to that for ischaemic heart disease. Mortality rates rose gradually between NS-SEC classes 1 and 4. However, the difference in mortality rates between NS-SEC classes 4 and 5, and between classes 6 and 7 were statistically significant. The socio-economic gradients were 6.2 for respiratory diseases and 5.2 for digestive diseases. 


\begin{tabular}{|c|c|c|c|c|c|c|c|c|c|}
\hline \multirow[b]{2}{*}{ NS-SEC analytic class } & \multicolumn{3}{|c|}{ All circulatory diseases } & \multicolumn{3}{|c|}{ Ischaemic heart disease } & \multicolumn{3}{|c|}{ Cerebrovascular diseases } \\
\hline & Rate & $\begin{array}{c}\text { Lower 95\% } \\
\text { confidence } \\
\text { interval }\end{array}$ & $\begin{array}{l}\text { Upper } 95 \% \\
\text { confidence } \\
\text { interval }\end{array}$ & Rate & $\begin{array}{c}\text { Lower } 95 \% \\
\text { confidence } \\
\text { interval }\end{array}$ & $\begin{array}{l}\text { Upper } 95 \% \\
\text { confidence } \\
\text { interval }\end{array}$ & Rate & $\begin{array}{l}\text { Lower } 95 \% \\
\text { confidence } \\
\text { interval }\end{array}$ & $\begin{array}{c}\text { Upper } 95 \% \\
\text { confidence } \\
\text { interval }\end{array}$ \\
\hline
\end{tabular}

1 Higher managerial and professional

2 Lower managerial and professional

3 Intermediate

4 Small employers and own account workers

5 Lower supervisory and technical

6 Semi-routine

7 Routine

Ratio of classes 7:1

$\begin{array}{ll}15 & 13 \\ 21 & 20 \\ 24 & 22 \\ 30 & 27 \\ 41 & 37 \\ 45 & 41 \\ 64 & 58 \\ 4.2 & 3.7\end{array}$

1 Directly age-standardised using European standard population.

2 NS-SEC assigned by the 'combined' method whereby if married the most advantaged class of either the woman or her husband is used to represent the woman's classification. Adjustments for the under-recording of death have been applied as described in Methods.

\section{Figure 5}

Age-standardised mortality rates ${ }^{1}$ for all circulatory diseases, ischaemic heart disease and cerebrovascular diseases by NS-SEC, women aged 25-59, 2001-03

England and Wales
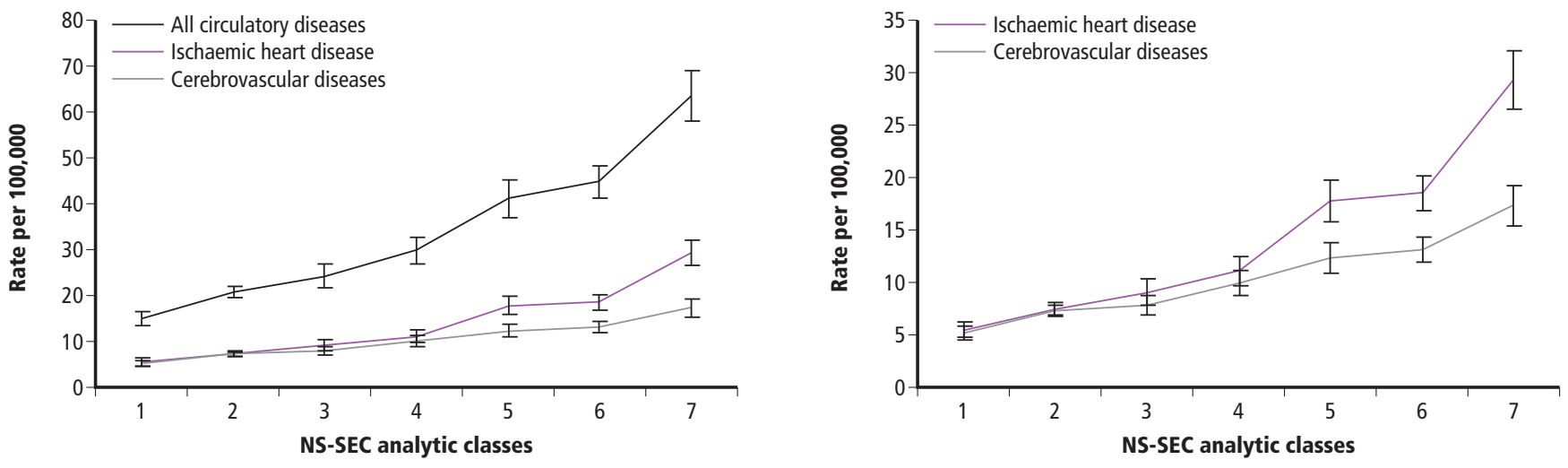

1 Directly age-standardised using European standard population.

2 NS-SEC assigned by the 'combined' method whereby if married the most advantaged class of either the woman or her husband is used to represent the woman's classification. Adjustments for the under-recording of death have been applied as described in Methods.

\section{Table 5}

Age-standardised mortality rates ${ }^{1}$ from all respiratory and all digestive diseases by NS-SEC, ${ }^{2}$ women aged $25-59,2001-03$

England and Wales

Age-standardised mortality rates' from all respiratory and all digestive diseases by NS-SEC, women aged $25-59,2001-03$

\begin{tabular}{|c|c|c|c|c|c|c|}
\hline England and Wales & & & & & & Rate per 100,000 \\
\hline \multirow[b]{2}{*}{ NS-SEC analytic class } & \multicolumn{3}{|c|}{ All respiratory diseases } & \multicolumn{3}{|c|}{ All digestive diseases } \\
\hline & Rate & $\begin{array}{c}\text { Lower } 95 \% \\
\text { confidence interval }\end{array}$ & $\begin{array}{c}\text { Upper } 95 \% \\
\text { confidence interval }\end{array}$ & Rate & $\begin{array}{c}\text { Lower 95\% } \\
\text { confidence interval }\end{array}$ & $\begin{array}{c}\text { Upper } 95 \% \\
\text { confidence interval }\end{array}$ \\
\hline
\end{tabular}

1 Higher managerial and professional

2 Lower managerial and professional

3 Intermediate

4 Small employers and own account workers

5 Lower supervisory and technical

6 Semi-routine

7 Routine

4
6
7
9
15
16
24
6.2

$\begin{array}{rr}3 & 5 \\ 5 & 6 \\ 6 & 9 \\ 7 & 10 \\ 13 & 17 \\ 14 & 17 \\ 21 & 27 \\ 5.0 & 7.5\end{array}$

Ratio of classes 7:1

1 Directly age-standardised using European standard population.

2 NS-SEC assigned by the 'combined' method whereby if married the most advantaged class of either the woman or her husband is used to represent the woman's classification. Adjustments for the under-recording of death have been applied as described in Methods. 


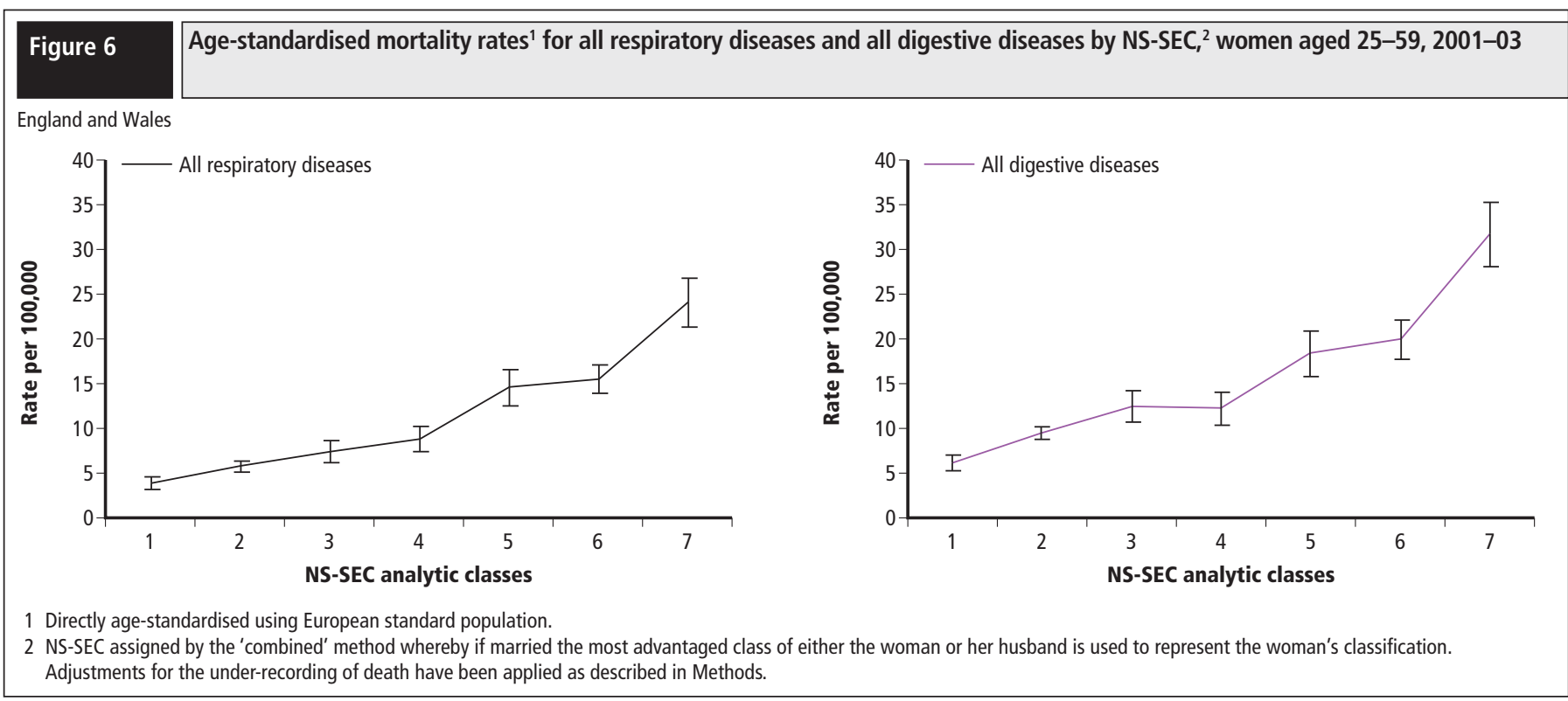

\section{Comparison of gradients by cause}

Figure 7 shows the socio-economic gradients for each of the disease categories. The smallest gradients were for all cancers combined and for breast cancer. The highest gradients were for respiratory diseases, digestive diseases and ischaemic heart disease, for which women in the least advantaged classes had mortality rates more than five times that of women in the most advantaged classes.

For all diseases studied, mortality rates for those classed as small employers and own account workers (NS-SEC class 4) were significantly lower than those classed as lower supervisory and technical (NS-SEC class 5). There were no significant differences between the rates for class 5 and the rates for those classed as semi-routine workers (NS-SEC class 6). Rates for those classed as routine workers (NS-SEC class 7) were statistically significantly higher than those classed as semi-routine workers (NS-SEC class 6) for all causes of death studied.

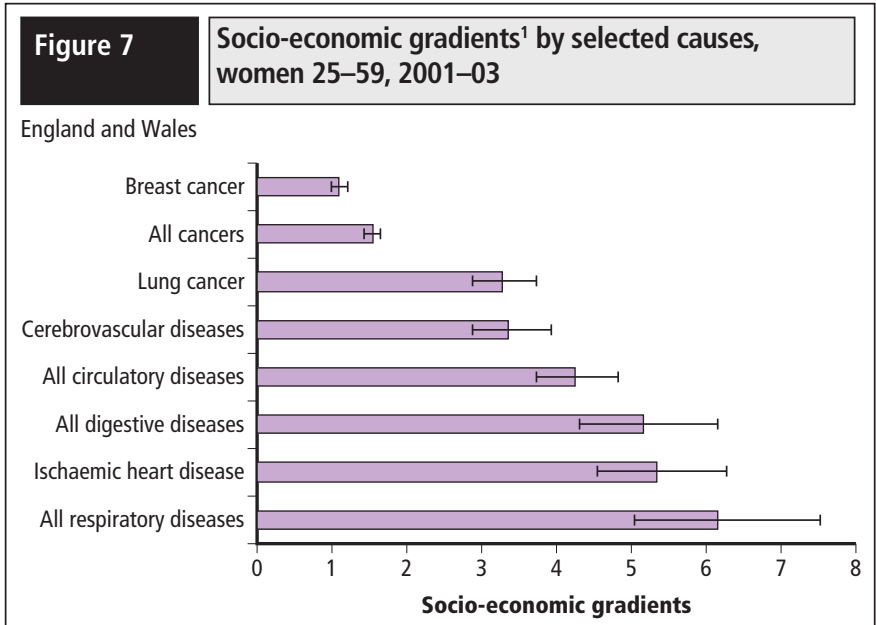

1 Ratio of mortality rates of NS-SEC class 7 to the mortality rate of NS-SEC Class 1. NS-SEC assigned by the 'combined' method whereby if married the most advantaged class of either the woman or her husband is used to represent the woman's classification. Adjustments for the under-recording of death have been applied as described in Methods.

\section{Mortality by selected region and cause}

The socio-economic variation of mortality by cause across regions was examined only for the North West and the South West, the regions with the highest and lowest all-cause mortality rates for most NS-SEC classes. Owing to the lack of statistically significant variation between regions for all-cause mortality, only mortality rates for the two major causes of death 'All cancers' ( 48 per cent of deaths) and 'All circulatory diseases' (18 per cent of deaths) are displayed in Table 6 and illustrated in Figure 8.

The estimated mortality rates for the North West are generally higher than those in the South West and statistically significantly so for NS-SEC classes 2, 3, 4 and 6 for all cancers combined, and for all classes except NS-SEC class 3 for circulatory diseases. By contrast, the socio-economic gradients are not statistically significantly different between the two regions for either major cause of death.
Age-standardised mortality rates ${ }^{1}$ for selected causes and regions by NS-SEC, ${ }^{2}$ women aged $25-59$, 2001-03

\begin{tabular}{|c|c|c|c|c|}
\hline \multirow{2}{*}{ NS-SEC analytic class } & \multicolumn{2}{|c|}{ All cancers } & \multicolumn{2}{|c|}{ All circulatory diseases } \\
\hline & North West & South West & North Wests & South West \\
\hline 1 Higher managerial and professional & 69 & 76 & 18 & 11 \\
\hline 2 Lower managerial and professional & 86 & 74 & 25 & 18 \\
\hline 3 Intermediate & 76 & 65 & 29 & 22 \\
\hline 4 Small employers and own account workers & 97 & 83 & 35 & 23 \\
\hline 5 Lower supervisory and technical & 107 & 98 & 51 & 38 \\
\hline 6 Semi-routine & 104 & 78 & 51 & 38 \\
\hline 7 Routine & 125 & 112 & 78 & 49 \\
\hline Ratio of classes 7:1 & 1.8 & 1.5 & 4.4 & 4.4 \\
\hline
\end{tabular}



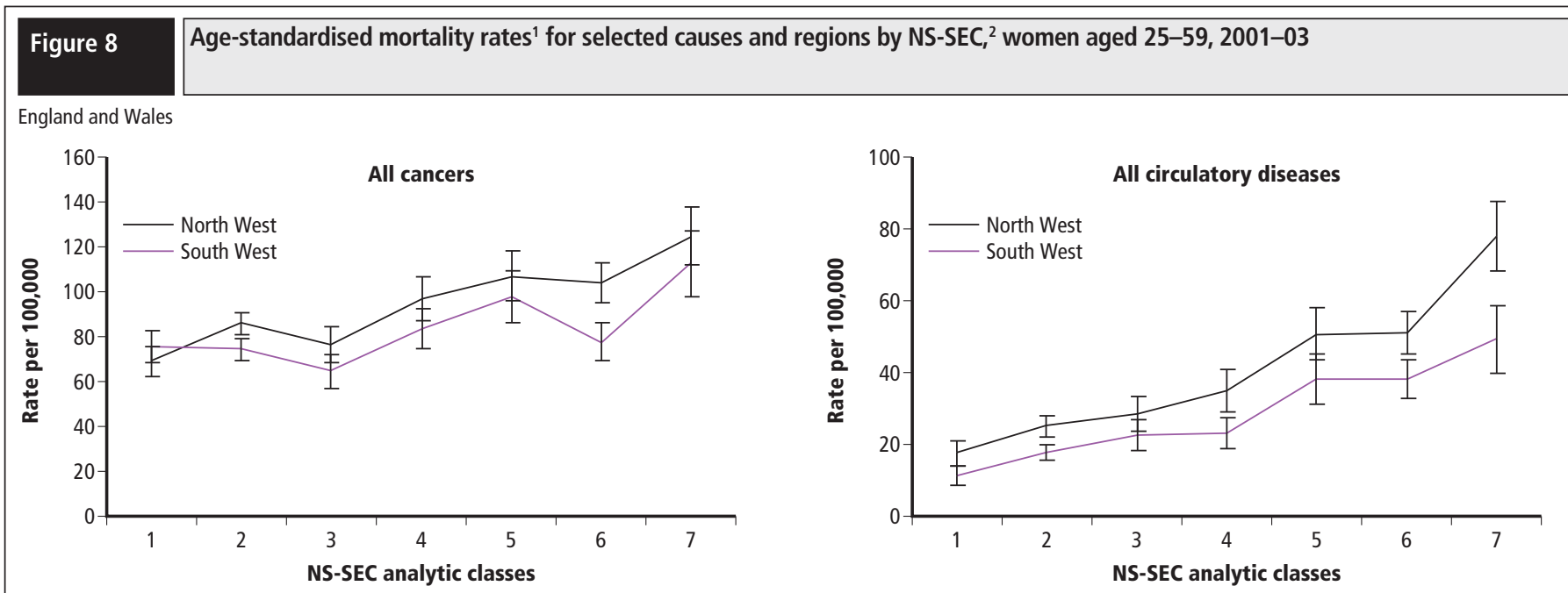

1 Directly age-standardised using European standard population.

2 NS-SEC assigned by the 'combined' method whereby if married the most advantaged class of either the woman or her husband is used to represent the woman's classification. Adjustments for the under-recording of death have been applied as described in Methods.

\section{Discussion}

\section{Regional mortality}

The results show variation in mortality rates between regions, with rates in the North West and North East consistently higher for all classes than rates in the South West and South East. A 'north-south' divide was also reported by authors considering female mortality by deprivation of area of residence both in the $1990 \mathrm{~s}^{16}$ and in the period covered in this study. ${ }^{17}$ A 'north west-south east divide' in self-reported health ${ }^{23}$ was also reported where the authors found that each of the seven NS-SEC classes had 'higher rates of poor health in Wales, the North East and the North West regions of England than elsewhere'.

This analysis also found that regional differences in mortality were smaller for the most advantaged classes and greater for the least advantaged classes. The comparative insensitivity of the most advantaged classes to regional effects has also been found by authors working on local area deprivation. ${ }^{17}$ That study found that 'those living in the least deprived areas had similar mortality rates, independent of region'. A similar pattern was reported in the third article in the current series which considered male socio-economic inequalities by region using NS-SEC. ${ }^{3}$ On the other hand, for the least advantaged, differences in mortality were more apparent between regions. The North West had mortality rate of 367 all-cause deaths per 100,000 person-years while the East of England had a rate of 253 all-cause deaths per 100,000 person years. A similar effect was found in the analysis of men, ${ }^{3}$ however the effect for men appeared to be stronger, since the mortality rate for the least advantaged class varied by approximately 80 per cent across regions, compared with a variation of approximately 45 per cent for women.

The current results do not indicate large regional variation in socio-economic gradients. The highest and lowest gradients were 2.1 and 3.0 respectively, but only two regions had significantly different socio-economic gradients to those for England and Wales as a whole. In the corresponding analysis of men $^{3}$ the gradients were similar, but there were significant differences in seven of the ten regions. This may be because relative differences between the sexes were smaller, or because the methodology adopted in the current analysis was not sufficiently sensitive to detect smaller differences.

The crucial aspect of the methodology that could affect the ability of this study to detect smaller differences involves the adjustments that have been made to the data to correct for the under-recording of occupation at death. These adjustments were made to correct for bias, but have necessarily resulted in larger confidence intervals for the estimates. Consequently there were difficulties in the detection of differences in smaller sub-samples, such as the smaller regions and also in smaller causes of death.

However, authors considering mortality by deprivation ${ }^{16,17}$ have also found that although mortality rates increase with deprivation for both sexes, the relationship was generally stronger for males. Figures published by authors studying self-reported health ${ }^{23}$ have indicated that relative differences between rates of those reporting 'not good' general health between the least and most advantaged NS-SEC classes for England were of the order of 2.7 for men, but only 2.2 for women. Hence there is some evidence in the literature that relative differences in regional socio-economic inequalities were smaller for women.

Many reasons have been suggested as to why there may be inequalities between regions, particularly in the most disadvantaged classes. ${ }^{3}$ Theoretical explanations include suggestions that the regional differences in mortality are associated with regional differences in unemployment risk, selective migration, differential concentrations of deprived areas and material disadvantage, or differing geographic patterns in health-related behaviours.

It is well established that there is a higher prevalence of ill-health and excess mortality in men and women who are unemployed. ${ }^{24,25}$ In addition, the authors suggested that job insecurity itself may constitute a psychosocial hazard to health. As unemployment and the risk of unemployment is greater in the north, ${ }^{26}$ this implies greater psychosocial stress on both men and women, particularly on those in routine or semiroutine occupations. Women may be affected directly, but possibly also through their husbands' employment position, potentially leading to increased stress and consequent mortality for women in the north, and particularly for the more disadvantaged.

Another potential explanation of regional inequalities is that of selective migration. ${ }^{27}$ This explanation suggests that those with good long-term health are more likely to move (for example to find work) while those with serious health problems are less likely to move and will have higher mortality rates. This is the so-called 'healthy migrant effect' which would lead to varying mortality rates between advantaged and disadvantaged areas. Some authors ${ }^{28}$ however have questioned whether this is a significant effect at the regional level. There are also questions as to how relevant this factor is for female mortality, although others have found that gender made little difference to the likelihood of migrants moving to more advantaged areas. ${ }^{29}$

A further explanation of regional differences may be that regions in the north have a higher concentration of deprived neighbourhoods, whose 
effect is not fully captured by the use of an occupational based socioeconomic measure such as NS-SEC. A study ${ }^{30}$ on cancer survival trends of males and females in England, for instance, found that survival was consistently lower for patients in the deprived Spearhead Primary Care Trust (PCT) Areas than for those resident in the rest of England. Most of these PCT areas are in the North, while there are none in the South West or South East. The disproportionate concentration of local deprivation may therefore be part of the explanation of the regional differences observed in the current study.

A related explanation is that regional differences may be directly related to material deprivation. Materialist explanations of inequalities suggest that individual incomes determine living conditions, including diet and housing quality, which consequently affect health and mortality. ${ }^{24}$ Both income inequality and mean income have indeed been found to be associated with mortality ${ }^{31}$ and it has been reported that in 2003-04 average incomes in the North East and the North West were among the smallest in England. ${ }^{32}$

Another explanation of the regional differences is that there may be regional differences in health-related behaviour between regions. Lifestyles have been recognised as contributing strongly to inequalities in mortality ${ }^{33}$ and differences in the prevalence of smoking, in particular, have been found to account for much of the variation in mortality between areas. ${ }^{34}$ More recently it has been shown in a study looking at self-reported health in women that the strongest independent effect on health was from smoking. ${ }^{35}$ It is known that levels of smoking vary quite markedly over both regions and social class. The General Household Survey found that in England in 2001, 30 per cent of women living in households classified to the manual group smoked cigarettes, compared with 20 per cent of those in households classified as non-manual. The GHS also reported on variation by region with 29 per cent of women smoking in the North West in 2001, but only 22 per cent in the South West. ${ }^{36}$ This would also seem to be a plausible explanation as to why more disadvantaged women in the north have a higher mortality rate than women in a similar position in the south.

\section{Mortality by cause}

\section{Malignant neoplasms}

The results presented here show a significant, but relatively small, socioeconomic gradient for all cancers combined (1.5), a marked gradient for lung cancer (3.3) but no significant gradient for breast cancer.

Many authors have also found strong socio-economic effects in lung cancer mortality. ${ }^{11,15}$ In addition, an international study ${ }^{37}$ comparing mortality rates for 1981-85 with 1991-95, found that in four western European countries rates of mortality from lung cancer in women had risen over the decade. The authors also found that this rise had been greater for women with lower educational levels in three of the countries studied. It has been estimated $^{38}$ that eight in ten lung cancer deaths in women are smokingattributable, so the socio-economic gradient observed in the current study may well reflect the differential smoking patterns in socio-economic groups. ${ }^{36}$ Many authors ${ }^{39,40}$ go further, postulating that 'the combination of the greatly increased mortality of smokers with the now much lower prevalence of smoking among the more affluent is the major contributor to the widening health inequalities, ${ }^{39}$ and that 'scope for reducing health inequalities related to social position is limited unless many smokers in lower social positions stop smoking, 39

In contrast, a flat or inverse socio-economic gradient in breast cancer mortality has been well documented. A study of mortality covering the 1970s and 1980s, which based socio-economic status on tenure and carownership, found that breast cancer did not appear to differ significantly between socio-economic groups. ${ }^{41}$ Later findings ${ }^{11}$ using the Registrar General's Social Class (RGSC) covering the late 1990s found an inverse gradient in breast cancer mortality and concluded that this inverse gradient had increased over the period 1986-2000. An international study ${ }^{42}$ also covering the 1990 s found that in eight of the 11 European populations studied, women with a higher education level had a greater risk of dying from breast cancer than women of a lower educational level. It has been suggested that this pattern may be related to the rise in incidence of later childbearing, which is more prominent in women in more advantaged classes. ${ }^{24,43}$

The comparatively flat socio-economic pattern in breast cancer mortality found in this study is probably attributable to the fact that while breast cancer incidence is higher among more affluent women, survival is also higher among these groups. Breast cancer incidence has been rising steadily, both in the age range invited for breast screening (50-69 years) and at other ages. ${ }^{44,45}$ Survival has also been rising, however. ${ }^{46,47}$ Thus although overall five-year survival rose from 68 per cent for women diagnosed in the late 1980 s to 80 per cent for women diagnosed in the late 1990s, the gap in survival between the most affluent and the most deprived was stable at around 6 per cent .

The results shown here for all cancers combined can be compared with those from an international study ${ }^{48}$ of women aged 20-74 in seven countries that used educational qualifications as a proxy for socioeconomic status. That study found an inverse gradient for all neoplasms in two eastern European countries, a small positive gradient in two Scandinavian countries and no significant gradient in the other three countries. The results presented here are more compatible with the Scandinavian results.

\section{Circulatory diseases}

This study found higher inequalities for all circulatory diseases and particularly for ischaemic heart disease, the socio-economic gradients were 4.3 and 5.4 respectively. Earlier authors looking at manual/nonmanual mortality rate ratios for the $1980 \mathrm{~s}^{15}$ and $1990 \mathrm{~s}^{11}$ also found that ischaemic heart disease had a ratio more than twice that of breast cancer. An international comparison ${ }^{48}$ also found stronger socio-economic gradients for cardiovascular disease than for all cancer amongst women.

The explanations that have been put forward for the existence of a socioeconomic gradient for circulatory diseases have included differential behavioural factors, material circumstances and exposure to psychosocial hazards at work. Some ${ }^{48}$ have suggested that inequalities in ischaemic heart disease could be due to a strong social patterning of behavioural risk factors (dietary factors, lack of physical activity, obesity) among women. Indeed, it has been found that in 2001, 30 per cent of women in routine occupations were obese compared with 16 per cent in higher managerial and professional occupations. ${ }^{49}$ The authors ${ }^{48}$ suggest that obesity may be a response of women to material disadvantage and/or psychosocial stressors. Support for psychosocial explanations comes from authors who found that high job strain and effort-reward imbalance seemed to increase the risk of cardiovascular mortality in a study that included both sexes. ${ }^{50}$ Others ${ }^{51}$ have also claimed that much of the difference in incidence of coronary heart disease can be explained by differences in the psychosocial work environment, with additional contributions from behavioural factors such as smoking and from some life-course factors. The psychosocial explanation is more problematic for this study, as the combined indicator allocates a substantial minority of women to their husband's occupation, rather than their own.

\section{Respiratory and digestive diseases}

This study found that mortality rates from these diseases exhibited a similar pattern to that of mortality rates from IHD. It has been estimated $^{38}$ that over 80 per cent of deaths from chronic obstructive lung disease can be attributed to smoking. As this disease accounts for over 70 per cent of respiratory disease deaths, it seems that the prevalence of smoking among differing social classes would again be an important factor in explaining socio-economic gradients observed. 
Approximately three-quarters of deaths from all digestive diseases are associated with liver disease. The relationship between alcohol consumption and liver disease is well founded ${ }^{52,53}$ but the relationship between alcohol consumption and socio-economic position is complex. Surveys on alcohol consumption have reported that women in managerial and professional households are more likely than other women to have drunk alcohol in the last week, ${ }^{36,54}$ and more likely to have drunk more in the week than other women $^{36}$. However, it has also been found ${ }^{54}$ that among women, those living in semi-routine and routine households were the most likely to indulge in binge drinking, that is drinking that exceeds twice the recommended daily limits. This later study also indicated that this drinking behaviour was far more common at younger ages. As other authors ${ }^{55}$ have found that, for younger women, those in the manual classes were more likely to die from alcohol-related causes, binge drinking may be an important factor in explaining the socio-economic mortality gradient found in this study.

Another possible explanation may be related to the individual occupations included in the more disadvantaged classes. A recent study of alcohol-related mortality by occupation ${ }^{56}$ found that, for women aged $20-64$, the seven occupations with the highest alcohol-related mortality included bar staff, waitresses, hairdressers and elementary office occupations. Most of these occupations would primarily be classified as semi-routine or routine, and may therefore also partly explain the socio-economic gradient found in this study.

\section{Mortality by selected region and cause}

Only the two regions with highest and lowest all-cause mortality rates were compared for all cancers and all circulatory diseases. There was evidence of differences in mortality rates between the two regions in all classes but the socio-economic gradients, as measured by the ratio of the mortality rates between the least and most advantaged classes, were not statistically significant. This may be partly due to methodological difficulties in detecting small differences noted earlier. However, other authors ${ }^{17}$ have also found relatively small differences between inequalities for these two diseases and regions. For instance, they found that the ratio of mortality rates between the first and fifth deprivation quintile for all cancers was 1.5 for the North West and 1.4 for the South West. For all circulatory diseases the ratio was 2.4 for both the North West and the South East.

\section{Comparison with male mortality}

The second article in this series described the socio-economic inequalities by cause of death for men aged $25-64$. $^{2}$ However, mortality rates for the different diseases between the two articles are not directly comparable for three main reasons. The first is that since women in 2001 retired at 60 , the working-age range was chosen to be $25-59$, and so the age range is not comparable. The second reason is that it is well known that the effect of disease varies considerably between sexes. The final reason is that the male analysis was conducted using the man's 'own' NSSEC, but the female analysis was done on a 'combined' quasi-household measure.

Given these provisos, although the mortality rates themselves are not comparable, the inequalities, that is the socio-economic gradients, may be compared. Table 7 presents the socio-economic gradients from the study of men alongside those presented above.

There are similarities in the patterns - inequalities in the diseases studied for both sexes are smallest for all cancers, but higher for lung cancer. In this study the gradients for lung cancer appear similar, other studies have also found that the ratio between most and least deprived were similar for males and females. ${ }^{17}$ However, others ${ }^{15,57}$ have found that women have an apparently greater relative risk than men of lung cancer.

The socio-economic gradient for ischaemic heart disease for women is markedly higher than that observed for men. A very similar pattern was observed in a study by area deprivation. ${ }^{16,17}$ The inequalities for women
Table 7

Socio-economic gradients for males and females by selected causes

\begin{tabular}{l|c|c}
\hline & Men $^{1}$ & Women $^{2}$ \\
\hline All Cancer & 1.8 & $1.5(1.4,1.7)$ \\
Cancer of Trachea, bronchus and lung & 3.7 & $3.3(2.9,3.7)$ \\
All circulatory diseases & 2.8 & $4.2(3.7,4.8)$ \\
Ischemic heart disease & 2.9 & $5.4(4.6,6.3)$ \\
Cerebrovascular disease & 2.9 & $3.4(2.9,3.9)$ \\
All respiratory diseases & 4.9 & $6.2(5.0,7.5)$ \\
All digestive diseases & 3.5 & $5.2(4.3,6.2)$ \\
\hline
\end{tabular}

1. From previous article in series ${ }^{1}$

2. $95 \%$ confidence interval in brackets

seem also to be higher for respiratory and digestive diseases, but given the provisos mentioned earlier and the breadth of the confidence intervals it is difficult to draw any firm conclusion.

\section{Limitations of the analysis}

Owing to the very sparse recording of women's occupations at death after normal retirement age, it was necessary to restrict the analysis to women aged $25-59$. Since only 8 per cent of adult women died age 59 or lower in the years 2001-03, this analysis is focused only on a minority of 'premature' deaths.

There are conceptual problems with the use of a 'combined' NS-SEC. NS-SEC is theoretically based on the employment relations of the individual, using the 'most advantaged' NS-SEC of a married couple implies that one can use the most advantaged NS-SEC of marriage partners as a proxy for the life-chances of each partner. This difficulty is fully discussed in the article on female all cause mortality. ${ }^{4}$

The results are sensitive to the adjustment to the deaths not classified to an occupied NS-SEC class. This adjustment was, of necessity, based on a relatively small sample (only 158 deaths) and resulted in much larger confidence intervals for the estimates presented than for the unadjusted figures. The unadjusted estimates are available for comparison in Appendix B, Table B1-B5. The size of the confidence intervals makes it much more difficult to detect differences in smaller sub-samples, and may partly explain why no significant differences between regional socio-economic gradients within causes were detected.

The outcome measure used throughout this series of articles, referred to above as the socio-economic gradient, has a number of limitations. As it is an age-standardised mortality ratio, it does not take account of the size of each class, nor what happens in the intervening classes. More complex outcome measures, such as the slope index of inequality or the GINI coefficient, ${ }^{58}$ could potentially be used in future studies.

The death registers during the period of this study did not recognise civil partnerships, and thus women in such partnerships have been treated as 'single'. The identical definition was used to obtain the census populations so the results presented above are consistent. However there is an argument for treating women in partnerships in the same way as married women.

\section{Conclusions}

This analysis has estimated standardised mortality rates by 'combined' NS-SEC for women aged $25-59$ in the period 2001-03 by region and cause of death.

A clear social gradient is evident for each region. Regional differences in absolute mortality rates were smaller for the most advantaged class, no region had a mortality rate statistically significantly different from 


\section{Key findings}

- There were socio-economic differences in mortality for women across Wales and all the English regions for the period 2001-03, with higher mortality rates in the more disadvantaged classes

- Regional differences in mortality were small for the most advantaged classes and greatest for the least advantaged

- The socio-economic gradient did not vary considerably from region to region for all-cause mortality - only two regions had gradients that were significantly different from that of England and Wales as a whole

- Among the causes of death analysed there were marked socio-economic differences in all respiratory diseases, all digestive diseases including liver diseases, ischaemic heart disease, all circulatory diseases, cerebrovascular disease and lung cancer

- There was no significant difference between mortality rates for the most and least advantaged for breast cancer

the England and Wales rate. Differences between regions were more pronounced for the least advantaged, but only three regions had rates that were statistically significantly different from the England and Wales rate.

Mortality rates were significantly higher for the North West region than for England and Wales as a whole for most NS-SEC classes, while mortality rates were lower in the South West region for most NS-SEC classes. None of the regional socio-economic gradients (that is the ratio between mortality rates for the least and most advantaged) were statistically significantly higher than that for England and Wales, as a whole.

A social gradient was also evident for all causes of death studied except for breast cancer. For breast cancer the mortality rates for the least and most advantaged were not statistically significantly different. For the other diseases studied there were marked socio-economic differences. The most disadvantaged women had approximately three times the mortality rate of more advantaged women for lung cancer and cerebrovascular disease, around five times as high for ischaemic heart disease and digestive diseases, and six times as high for respiratory diseases.

Mortality rates for the regions with generally the lowest and highest mortality rates were compared for the two largest causes studied, 'all cancers' and 'all circulatory diseases'. There were statistically significant differences between the mortality rates of the two regions in most NSSEC classes, but no statistically significant differences in the socioeconomic gradient between the two regions.

In comparison to men, there were similarities in the pattern of inequalities between diseases. Inequalities were smallest for all cancer and largest for respiratory and digestive diseases. Inequalities for ischaemic heart disease were particularly high for women.

\section{References}

1. White C, Glickman M, Johnson B and Corbin T (2007) 'Social inequalities in adult male mortality by the National Statistics SocioEconomic Classification, England and Wales, 2001-03', Health Statistics Quarterly 36, 6-23. Available on the Office for National Statistics website at:
www.statistics.gov.uk/statbase/Product.asp?vlnk=6725

2. White C, Edgar G and Siegler V (2008) 'Social inequalities in male mortality for selected causes of death by the National Statistics Socio-Economic Classification, England and Wales, 2001-03', Health Statistics Quarterly 38, 19-31. Available on the Office for National Statistics website at:

www.statistics.gov.uk/statbase/Product.asp?vlnk=6725

3. Siegler V, Langford A and Johnson B (2008) 'Regional differences in male mortality using the National Statistics Socio-economic Classification, England and Wales, 2001-03', Health Statistics Quarterly 40, 6-18. Available on the Office for National Statistics website at: www.statistics.gov.uk/statbase/Product.asp?vlnk=6725

4. Langford A and Johnson B (2009) 'Social inequalities in female mortality by the National Statistics Socio-economic Classification, England and Wales, 2001-03', Health Statistics Quarterly 42, 6-21. Available on the Office for National Statistics website at: www.statistics.gov.uk/statbase/Product.asp?vlnk=6725

5. Black D, Morris J, Smith C and Townsend P (1980) Inequalities in health: report of a research working group. Department of Health and Social Security: London.

6. Acheson D (1998) Independent inquiry into inequalities in health, The Stationery Office: London.

7. Department of Health (2003) Tackling Health Inequalities: A programme for action, Department of Health: London.

8. Department of Health (2007) Tackling Health Inequalities: 2007 Status Report on the Programme for Action, Department of Health: London.

9. Goldblatt P (ed) (1990), Longitudinal Study: Mortality and Social Organisation, Series LS No.6, Her Majesty’s Stationery Office: London.

10. Drever F and Whitehead M (eds) (1997), Health Inequalities: Decennial Supplement, Series DS no. 15, The Stationery Office: London.

11. White C, van Galen F and Chow Y H (2003) 'Trends in social class differences in mortality by cause, 1986 to 2000', Health Statistics Quarterly 20, 25-37. Available on the Office for National Statistics website at: www.statistics.gov.uk/statbase/Product.asp?vlnk=6725

12. Moser K, Goldblatt P and Pugh H (1990) 'Occupational Mortality of Women in Employment' in Goldblatt P (ed), Longitudinal Study: Mortality and Social Organisation, Series LS no.6, Her Majesty's Stationery Office: London.

13. Erikson R (1984) 'Social class of men, women and families', Sociology, 18, 500-14.

14. Erikson R (2006) 'Social class assignment and mortality in Sweden', Social Science in Medicine 62 (9) 2151-60.

15. Harding S, Bethune A, Maxwell R, and Brown J (1997) 'Mortality trends using the Longitudinal study' in Drever F and Whitehead M (eds), Health Inequalities: Decennial Supplement, Series DS no. 15, The Stationery Office: London, 143-55.

16. Uren Z and Fitzpatrick J (2001) in Griffiths C and Fitzpatrick J (eds), Geographic Variations in Health, Series DS no 16 (Chapter 11), 326-36. The Stationery Office: London.

17. Romeri E, Baker A and Griffiths C (2006) 'Mortality by deprivation and cause of death in England and Wales, 1999-2003', Health Statistics Quarterly 32, 19-34. Available on the Office for National Statistics website at: www.statistics.gov.uk/statbase/Product.asp? vlnk $=6725$

18. Goldthorpe J (2000) 'Social class and the differentiation of employment contracts' in Goldthorpe J (ed), On Sociology: Numbers, Narratives and the Integration of Research and Theory, Oxford University Press: Oxford.

19. Rose D and Pevalin D (eds) (2003) A Researcher's Guide to the National Statistics Socio-economic Classification, Sage: London.

20. Office for National Statistics, The National Statistics Socio-economic 
Classification on-line edition. Available on the Office for National Statistics website at:

www.statistics.gov.uk/statbase/Product.asp?vlnk=13561

21. Office for National Statistics, Geography User Guide. Available on the Office for National Statistics website at:

www.statistics.gov.uk/statbase/Product.asp?vlnk $=7428 \& \mathrm{Pos}=2 \& \mathrm{Col}$ Rank=1\&Rank=240 per cent 20 (geog)

22. Rooney C and Smith S (2000) 'Implementation of ICD-10 for mortality data in England and Wales from January 2001', Health Statistics Quarterly 8, 41-51. Available on the Office for National Statistics website at: www.statistics.gov.uk/statbase/Product.asp?vlnk $=6725$

23. Doran T, Drever F and Whitehead M (2004) 'Is there a north-south divide in social class inequalities in health in Great Britain? Cross sectional study using data from the 2001 Census', British Medical Journal, 328, 1043-45.

24. Bartley M (2004) Health Inequality: an introduction to theories, concepts and methods, Polity Press: Cambridge.

25. Bartley M, Ferrie J and Montgomery S (1999) 'Living in a highunemployment economy: understanding the health consequences' in Marmot M and Wilkinson R G (eds) Social Determinants of Health, Oxford University Press: Oxford.

26. Summerfield C and Babb P (eds) (2003) 'Unemployment rates: by region, 2002', Social Trends 33, 83. Available on the Office for National Statistics website at: www.statistics.gov.uk/statbase/ssdataset.asp?vlnk=6280

27. Griffiths C, Goldblatt P and Fitzpatrick J (2001) 'Geographic variations in health: main findings and implications for the future' in Griffiths C and Fitzpatrick J (eds), Geographic Variations in Health, Series DS no 16 (Chapter 11), 360-68. The Stationery Office: London.

28. Brimblecombe N, Dorling D and Shaw M (1999) 'Mortality and migration in Britain, first results from the British Household Panel Survey', Social Science and Medicine 49, 981-88.

29. Connolly S, O'Reilly D and Rosato M (2007) 'Increasing inequalities in health: Is it an artefact caused by the selective movement of people?', Social Science \& Medicine 64, 2008-15.

30. Ellis L, Rachet B, Shah A et al (2009) 'Trends in cancer survival in Spearhead Primary Care Trusts in England, 1998-2004', Health Statistics Quarterly 41, 7-12. Available on the Office for National Statistics website at: www.statistics.gov.uk/statbase/Product.asp?vlnk=6725

31. Stanistreet D, Scott-Samuel A and Bellis M A (1999) 'Income inequality and mortality in England', Journal of Public Health Medicine 21, 205-07.

32. Her Majesty's Revenue and Customs. Income Distribution. Accessed 27 October 2009, available at:

www.hmrc.gov.uk/stats/income_distribution/3_13_apr06.PDF

33. Balia S and Jones A ( 2008) 'Mortality, lifestyle and socio-economic status', Journal of Health Economics 27, 1-26.

34. Law M and Morris J K (1998) 'Why is mortality higher in poorer areas and in more northern areas of England and Wales?', Journal of Epidemiology and Community Health 52, 344-52.

35. Sacker A, Bartley M, Firth D et al (2001) 'Dimensions of social inequality in the health of women in England: occupational, material and behavioural pathways', Social Science \& Medicine 52, 763-81.

36. Office for National Statistics (2002) Living in Britain 2001. Available on the Office for National Statistics website at: www.statistics.gov.uk/lib2001/Section3536.html

37. Mackenbach J P, Bos V, Andersen O et al (2003) 'Widening socioeconomic inequalities in mortality in six Western European countries' International Journal of Epidemiology 32, 830-37.

38. Twigg L, Moon G and Walker S (2004) The Smoking Epidemic in England, Health Development Agency: London.

39. Gruer L, Hart C L, Gordon D S et al (2009) 'Effect of tobacco smoking on survival of men and women by social position: a 28 year cohort study', British Medical Journal 338, 480.
40. Jarvis M J and Wardle J (1999) 'Social patterning of individual health behaviours: the case of cigarette smoking' in Marmot M and Wilkinson R G (eds) Social Determinants of Health, Oxford University Press: Oxford

41. Smith J and Harding S (1997) 'Mortality of women and men using alternative social classifications' in Drever F and Whitehead M (eds), Health Inequalities: Decennial Supplement, Series DS no. 15, The Stationery Office: London, 143-55.

42. Strand B H, Kunst A, Huisman M et al (2007) 'The reversed social gradient: Higher breast cancer mortality in the higher educated compared to the lower educated. A comparison of 11 European populations during the 1990s', European Journal of Cancer 42, 1200-07.

43. Brown J, Harding S, Bethune A et al (1997) 'Incidence of Health of the Nation cancers by social class', Population Trends 90, 40-48.

44. Westlake S and Cooper N (2008) 'Cancer incidence and mortality: trends in the United Kingdom and constituent countries 1993 to 2004' Health Statistics Quarterly 38, 33-43. Available on the Office for National Statistics website at: www.statistics.gov.uk/statbase/Product.asp?vlnk $=6725$

45. Rowan S (2007) 'Trends in cancer incidence by deprivation, England and Wales, 1990-2002', Health Statistics Quarterly 36, 24-35. Available on the Office for National Statistics website at: www.statistics.gov.uk/statbase/Product.asp?vlnk=6725

46. Quinn M J, Cooper N, Rachet B et al (2008) 'Survival from cancer of the breast in women in England and Wales up to 2001', British Journal of Cancer 99 (Suppl 1), 53-55.

47. Coleman M P, Rachet B, Woods L M et al (2004) 'Trends in socioeconomic inequalities in cancer survival in England and Wales up to 2001', British Journal of Cancer 90, 1367-73.

48. Mackenbach J P, Kunst A E, Groenhof F et al (1999) 'Socio-economic Inequalities in Mortality Among Women and Among Men: An International Study', American Journal of Public Health 89, 1800-06.

49. Office for National Statistics (2004) 'Obesity among adults: by sex and NS-SEC 2001', Social Trends 34, 111-12. Available on the Office for National Statistics website at: www.statistics.gov.uk/statbase/ssdataset.asp?vlnk=7447

50. Kivimaki M, Leino-Arjas P, Luukkonen R et al (2002) 'Work stress and risk of cardiovascular mortality: prospective cohort study of industrial employees' British Medical Journal 325, 857.

51. Marmot M G, Bosma H, Hemingway H et al (1997) 'Contribution of job control and other risk factors to social variations in coronary heart disease incidence' The Lancet 350, 235-39.

52. Brunn K, Edwards G, Lumio M et al (1975) Alcohol Control Policies in Public Health Perspective, Finnish Foundation for Alcohol Studies: Helsinki.

53. Anderson P (1995) 'Alcohol and the risk of physical harm' in Holder $\mathrm{H}$ and Edwards $\mathrm{G}$ (eds), Alcohol and Public Policy:evidence and Issues, 82-113.

54. Erens B (2003) 'Alcohol Consumption' in Sproston K and Primatesta P (eds), 'Health Survey for England 2003', Department of Health: London.

55. Harrison L and Gardiner E (2002) 'Do the rich really die young? Alcohol related mortality and social class in Great Britain 1988-94', Addiction 94:12, 1871-80.

56. Romeri E, Baker A and Griffiths C ( 2007) 'Alcohol-related deaths by occupation, England and Wales, 2001-05', Health Statistics Quarterly 35, 6-12. Available on the Office for National Statistics website at: www.statistics.gov.uk/statbase/Product.asp?vlnk $=6725$

57. Payne S (2001) 'Smoke like a man, die like a man?: A review of the relationship between gender, sex and lung cancer', Social Science and Medicine 53, 1067-68.

58. South East Public Health Observatory (2005). 'The Public Health Observatory Handbook of Health Inequalities Measurement'. Accessed on 27 October 2009, available at: www.sepho.org.uk/ extras/rch_handbook.aspx 
Appendix A

Table A1

Number of deaths by NS-SEC 1 and age, women aged 25-59, 2001-03

Government Office Regions of England, Wales

Numbers

\begin{tabular}{l|c|c|c|c|c|c|c|c|c|}
\hline & $\begin{array}{c}\text { Higher managerial } \\
\text { and professional }\end{array}$ & $\begin{array}{c}\text { Lower managerial } \\
\text { and professional }\end{array}$ & Intermediate & $\begin{array}{c}\text { Small employers } \\
\text { and own account } \\
\text { workers }\end{array}$ & $\begin{array}{c}\text { Lower supervisory } \\
\text { and technical }\end{array}$ & Semi-routine & Routine & Others ${ }^{2}$ & Total \\
\hline
\end{tabular}

North West

$25-29$

$30-34$

$35-39$

40-44

45-49

50-54

$55-59$

Total

Percentage

$\begin{array}{rr}13 & 42 \\ 39 & 65 \\ 60 & 120 \\ 85 & 199 \\ 128 & 347 \\ 197 & 562 \\ 296 & 722 \\ 818 & 2,058\end{array}$

$\begin{array}{rr}42 & 48 \\ 65 & 65 \\ 120 & 90 \\ 199 & 130 \\ 347 & 177 \\ 562 & 280 \\ 722 & 358 \\ & \\ 2,058 & 1,148 \\ 21.1 & 11.8\end{array}$

$\begin{array}{rr}48 & 12 \\ 65 & 21 \\ 90 & 41 \\ 130 & 72 \\ 177 & 121 \\ 280 & 218 \\ 358 & 336 \\ 1,148 & 820 \\ 11.8 & 8.4\end{array}$

North East

$25-29$
$30-34$
$35-39$
$40-44$
$45-49$
$50-54$
$55-59$

3

30-34

-44

50-54

Total

Percentage

$\begin{array}{rrr}13 & 15 & 4 \\ 20 & 21 & 7 \\ 42 & 20 & 16 \\ 80 & 46 & 27 \\ 123 & 69 & 41 \\ 221 & 104 & 72 \\ 228 & 130 & 78 \\ 727 & 405 & 245 \\ 20.2 & 11.2 & 6.8\end{array}$

$\begin{array}{rr}12 & 17 \\ 21 & 35 \\ 41 & 59 \\ 72 & 89 \\ 21 & 153 \\ 18 & 263 \\ 36 & 420 \\ 20 & 1,035 \\ 8.4 & 10.6\end{array}$

51
97
127
187
287
442
600
1,793
18.4

32
63
85
148
227
351
532
1,438
14.8

$\begin{array}{rr}42 & 258 \\ 55 & 440 \\ 64 & 647 \\ 76 & 986 \\ 114 & 1,554 \\ 121 & 2,434 \\ 151 & 3,414 \\ 623 & 9,733 \\ 6.4 & \end{array}$

Yorkshire and The Humber

$\begin{array}{lrr}25-29 & 11 & 29 \\ 30-34 & 23 & 62 \\ 35-39 & 42 & 101 \\ 40-44 & 53 & 140 \\ 45-49 & 105 & 216 \\ 50-54 & 134 & 343 \\ 55-59 & 184 & 428 \\ \text { Total } & 552 & 1,319 \\ \text { Percentage } & 9.0 & 21.5\end{array}$

\section{East Midlands}

$\begin{array}{lrr}25-29 & 9 & 24 \\ 30-34 & 24 & 44 \\ 35-39 & 36 & 85 \\ 40-44 & 59 & 124 \\ 45-49 & 90 & 165 \\ 50-54 & 148 & 320 \\ 55-59 & 184 & 431 \\ \text { Total } & 550 & 1,194 \\ \text { Percentage } & 10.3 & 22.4\end{array}$

West Midlands

$\begin{array}{crr}25-29 & 14 & 19 \\ 30-34 & 18 & 52 \\ 35-39 & 34 & 86 \\ 40-44 & 88 & 150 \\ 45-49 & 91 & 198 \\ 50-54 & 161 & 381 \\ 55-59 & 239 & 501 \\ \text { Total } & 646 & 1,386 \\ \text { Percentage } & 9.8 & 21.0\end{array}$

East of England

$\begin{array}{lrr}25-29 & 15 & 46 \\ 30-34 & 32 & 62 \\ 35-39 & 53 & 103 \\ 40-44 & 81 & 126 \\ 45-49 & 136 & 221 \\ 50-54 & 199 & 396 \\ 55-59 & 308 & 543 \\ \text { otal } & 824 & 1,498 \\ \text { Percentage } & 13.2 & 23.9\end{array}$

London

\begin{tabular}{crrrr}
$\begin{array}{l}\text { London } \\
25-29\end{array}$ & 31 & 60 & 37 & 17 \\
$30-34$ & 47 & 107 & 74 & 25 \\
$35-39$ & 88 & 180 & 115 & 50 \\
$40-44$ & 121 & 246 & 167 & 68 \\
$45-49$ & 150 & 305 & 171 & 92 \\
$50-54$ & 187 & 455 & 278 & 176 \\
$55-59$ & 248 & 572 & 375 & 269 \\
Total & 873 & 1,925 & 1,216 & 698 \\
Percentage & 10.6 & 23.4 & 14.8 & 8.5 \\
\hline
\end{tabular}

$\begin{array}{rr}5 & 2 \\ 14 & 3 \\ 22 & 50 \\ 40 & 66 \\ 59 & 92 \\ 122 & 160 \\ 186 & 249 \\ 447 & 67 \\ 12.4 & 18.6\end{array}$

$\begin{array}{rrrr}21 & 11 & 13 & 86 \\ 33 & 21 & 19 & 143 \\ 50 & 28 & 22 & 213 \\ 66 & 50 & 31 & 358 \\ 92 & 94 & 40 & 570 \\ 160 & 161 & 53 & 960 \\ 249 & 239 & 65 & 1,269 \\ 671 & 604 & 243 & 3,599 \\ 18.6 & 16.8 & 6.8 & \end{array}$

$\begin{array}{rr}25 & 7 \\ 40 & 19 \\ 42 & 36 \\ 70 & 50 \\ 112 & 80 \\ 155 & 146 \\ 229 & 214 \\ 673 & 551 \\ 11.0 & 9.0\end{array}$

$\begin{array}{rr}7 & 8 \\ 19 & 21 \\ 36 & 36 \\ 50 & 58 \\ 80 & 104 \\ 146 & 151 \\ 214 & 280 \\ 551 & 657 \\ 9.0 & 10.7\end{array}$

$\begin{array}{rr}8 & 48 \\ 21 & 48 \\ 36 & 86 \\ 58 & 142 \\ 104 & 168 \\ 151 & 253 \\ 280 & 397 \\ 657 & 1,142 \\ 10.7 & 18.6\end{array}$

$\begin{array}{rrrr}48 & 28 & 26 & 182 \\ 48 & 32 & 27 & 273 \\ 86 & 67 & 37 & 448 \\ 142 & 101 & 40 & 654 \\ 168 & 136 & 56 & 977 \\ 253 & 208 & 58 & 1,446 \\ 397 & 353 & 85 & 2,170 \\ 1,142 & 924 & 330 & 6,150 \\ 18.6 & 15.0 & 5.4 & \end{array}$

$\begin{array}{rr}17 & 8 \\ 29 & 17 \\ 45 & 28 \\ 54 & 41 \\ 91 & 67 \\ 144 & 116 \\ 191 & 212 \\ 572 & 488 \\ 10.7 & 9.2\end{array}$

$\begin{array}{rr}8 & 6 \\ 17 & 22 \\ 28 & 30 \\ 41 & 44 \\ 67 & 84 \\ 116 & 128 \\ 212 & 235 \\ 488 & 550 \\ 9.2 & 10.3\end{array}$

6
22
30
44
84
128
235
550
10.3

22
53
67
103
144
219
332
942
17.7

$\begin{array}{rrr}22 & 18 & 125 \\ 30 & 26 & 245 \\ 38 & 29 & 359 \\ 72 & 33 & 531 \\ 98 & 41 & 780 \\ 185 & 56 & 1,318 \\ 313 & 78 & 1,976 \\ 757 & 281 & 5,334 \\ 14.2 & 5.3 & \end{array}$

$\begin{array}{rr}26 & 8 \\ 33 & 16 \\ 52 & 29 \\ 75 & 44 \\ 93 & 83 \\ 187 & 147 \\ 230 & 229 \\ 695 & 555 \\ 10.5 & 8.4\end{array}$

$\begin{array}{rr}8 & 13 \\ 16 & 22 \\ 29 & 43 \\ 44 & 66 \\ 83 & 102 \\ 147 & 206 \\ 229 & 323 \\ 555 & 776 \\ 8.4 & 11.8\end{array}$

13
22
43
66
102
206
323
776
11.8

32
63
66
118
207
323
452
1,262
19.1

$\begin{array}{rr}23 & 24 \\ 41 & 30 \\ 54 & 33 \\ 97 & 38 \\ 136 & 52 \\ 244 & 77 \\ 342 & 87 \\ 937 & 341 \\ 14.2 & 5.2\end{array}$

$$
\begin{array}{r}
158 \\
275 \\
397 \\
676 \\
962 \\
1,726 \\
2,404 \\
6,598
\end{array}
$$

\begin{tabular}{|c|c|c|c|c|c|c|}
\hline 27 & 5 & 9 & 31 & 14 & 18 & 166 \\
\hline 47 & 20 & 20 & 46 & 30 & 30 & 287 \\
\hline 62 & 33 & 29 & 91 & 47 & 35 & 453 \\
\hline 80 & 56 & 48 & 101 & 61 & 33 & 586 \\
\hline 126 & 88 & 90 & 161 & 95 & 49 & 965 \\
\hline 209 & 161 & 146 & 253 & 149 & 60 & 1,574 \\
\hline 284 & 246 & 217 & 354 & 198 & 80 & 2,231 \\
\hline 835 & 609 & 559 & 1,037 & 594 & 305 & 6,262 \\
\hline 13.3 & 9.7 & 8.9 & 16.6 & 9.5 & 4.9 & \\
\hline
\end{tabular}

1 NS-SEC assigned by the 'combined' method whereby if married the most advantaged class of either the woman or her husband is used to represent the woman's classification. Adjustments for the under-recording of death have been applied as described in Methods.

2 Includes full-time students, never worked, long-term unemployed, inadequately described and not classified for other reasons. 


\begin{tabular}{|c|c|c|c|c|c|c|c|c|c|}
\hline & $\begin{array}{l}\text { Higher managerial } \\
\text { and professional }\end{array}$ & $\begin{array}{l}\text { Lower managerial } \\
\text { and professional }\end{array}$ & Intermediate & $\begin{array}{c}\text { Small employers } \\
\text { and own account } \\
\text { workers }\end{array}$ & $\begin{array}{c}\text { Lower supervisory } \\
\text { and technical }\end{array}$ & Semi-routine & Routine & Others ${ }^{2}$ & Total \\
\hline \multicolumn{10}{|l|}{ South East } \\
\hline $25-29$ & 29 & 54 & 34 & 8 & 14 & 46 & 28 & 32 & 246 \\
\hline $30-34$ & 61 & 108 & 57 & 22 & 30 & 70 & 44 & 39 & 431 \\
\hline $35-39$ & 102 & 177 & 87 & 36 & 61 & 90 & 63 & 57 & 673 \\
\hline $40-44$ & 155 & 226 & 129 & 78 & 82 & 150 & 82 & 59 & 961 \\
\hline $45-49$ & 217 & 334 & 170 & 112 & 116 & 197 & 115 & 70 & 1,330 \\
\hline $50-54$ & 345 & 643 & 306 & 192 & 206 & 298 & 187 & 103 & 2,280 \\
\hline $55-59$ & 456 & 871 & 412 & 304 & 339 & 479 & 310 & 127 & 3,297 \\
\hline Total & 1,365 & 2,414 & 1,195 & 752 & 848 & 1,329 & 828 & 486 & 9,218 \\
\hline Percentage & 14.8 & 26.2 & 13.0 & 8.2 & 9.2 & 14.4 & 9.0 & 5.3 & \\
\hline \multicolumn{10}{|l|}{ South West } \\
\hline $25-29$ & 10 & 20 & 18 & 6 & 10 & 26 & 20 & 18 & 128 \\
\hline $30-34$ & 22 & 59 & 40 & 14 & 11 & 38 & 28 & 17 & 229 \\
\hline $35-39$ & 49 & 87 & 51 & 30 & 45 & 58 & 44 & 28 & 393 \\
\hline $40-44$ & 76 & 127 & 64 & 45 & 48 & 107 & 52 & 38 & 559 \\
\hline $45-49$ & 107 & 232 & 109 & 91 & 92 & 158 & 102 & 48 & 939 \\
\hline $50-54$ & 170 & 391 & 160 & 166 & 146 & 236 & 142 & 61 & 1,472 \\
\hline $55-59$ & 217 & 518 & 218 & 285 & 225 & 318 & 212 & 78 & 2,071 \\
\hline Total & 651 & 1,434 & 660 & 638 & 578 & 940 & 601 & 289 & 5,791 \\
\hline Percentage & 11.2 & 24.8 & 11.4 & 11.0 & 10.0 & 16.2 & 10.4 & 5.0 & \\
\hline \multicolumn{10}{|l|}{ Wales } \\
\hline $25-29$ & 6 & 14 & 12 & 5 & 5 & 17 & 13 & 13 & 84 \\
\hline $30-34$ & 9 & 40 & 25 & 13 & 15 & 28 & 19 & 24 & 174 \\
\hline $35-39$ & 16 & 55 & 30 & 12 & 21 & 51 & 38 & 33 & 255 \\
\hline $40-44$ & 34 & 92 & 49 & 40 & 30 & 61 & 64 & 35 & 405 \\
\hline $45-49$ & 49 & 149 & 65 & 59 & 71 & 107 & 88 & 45 & 632 \\
\hline $50-54$ & 86 & 213 & 92 & 85 & 113 & 158 & 140 & 49 & 936 \\
\hline $55-59$ & 126 & 312 & 166 & 161 & 191 & 239 & 233 & 71 & 1,499 \\
\hline Total & 326 & 873 & 439 & 375 & 445 & 661 & 596 & 270 & 3,985 \\
\hline Percentage & 8.2 & 21.9 & 11.0 & 9.4 & 11.2 & 16.6 & 14.9 & 6.8 & \\
\hline
\end{tabular}

1 NS-SEC assigned by the 'combined' method whereby if married the most advantaged class of either the woman or her husband is used to represent the woman's classification. Adjustments for the under-recording of death have been applied as described in Methods.

2 Includes full-time students, never worked, long-term unemployed, inadequately described and not classified for other reasons.

\begin{tabular}{|c|c|c|c|c|c|c|c|c|c|}
\hline Table A2 & \multicolumn{9}{|c|}{ Number of deaths by NS-SEC, ${ }^{1}$ cause $^{2}$ and age, women aged $25-59,2001-03$} \\
\hline \multicolumn{9}{|c|}{ England and Wales } & Numbers \\
\hline & $\begin{array}{c}\text { Higher managerial } \\
\text { and professional }\end{array}$ & $\begin{array}{l}\text { Lower managerial } \\
\text { and professional }\end{array}$ & Intermediate & $\begin{array}{c}\text { Small employers } \\
\text { and own account } \\
\text { workers }\end{array}$ & $\begin{array}{c}\text { Lower supervisory } \\
\text { and technical }\end{array}$ & Semi-routine & Routine & Others ${ }^{3}$ & Total \\
\hline \multicolumn{10}{|c|}{ All malignant neoplasms } \\
\hline $25-29$ & 54 & 99 & 58 & 21 & 30 & 64 & 32 & 28 & 387 \\
\hline $30-34$ & 138 & 270 & 137 & 60 & 65 & 123 & 83 & 44 & 921 \\
\hline $35-39$ & 270 & 477 & 218 & 133 & 156 & 248 & 145 & 79 & 1,727 \\
\hline $40-44$ & 472 & 774 & 366 & 260 & 228 & 423 & 270 & 105 & 2,897 \\
\hline $45-49$ & 730 & 1,289 & 574 & 439 & 468 & 721 & 430 & 182 & 4,832 \\
\hline $50-54$ & 1,142 & 2,363 & 1,035 & 857 & 867 & 1,217 & 843 & 245 & 8,568 \\
\hline $55-59$ & 1,589 & 3,110 & 1,439 & 1,316 & 1,371 & 1,805 & 1,349 & 327 & 12,307 \\
\hline Total & 4,395 & 8,383 & 3,827 & 3,086 & 3,186 & 4,600 & 3,150 & 623 & 31,639 \\
\hline Percentage & 13.9 & 26.5 & 12.1 & 9.8 & 10.1 & 14.5 & 10.0 & 2.0 & \\
\hline \multicolumn{10}{|c|}{ Breast cancer } \\
\hline $25-29$ & 12 & 15 & 9 & 5 & 5 & 5 & 5 & 2 & 59 \\
\hline $30-34$ & 47 & 79 & 43 & 17 & 15 & 30 & 24 & 10 & 266 \\
\hline $35-39$ & 129 & 197 & 93 & 45 & 51 & 102 & 50 & 24 & 691 \\
\hline $40-44$ & 198 & 321 & 143 & 90 & 85 & 136 & 92 & 34 & 1,098 \\
\hline $45-49$ & 292 & 455 & 192 & 120 & 155 & 207 & 121 & 59 & 1,601 \\
\hline $50-54$ & 410 & 738 & 305 & 229 & 241 & 341 & 201 & 61 & 2,526 \\
\hline $55-59$ & 484 & 881 & 380 & 314 & 286 & 372 & 278 & 76 & 3,072 \\
\hline Total & 1,572 & 2,687 & 1,165 & 821 & 839 & 1,194 & 771 & 265 & 9,313 \\
\hline Percentage & 16.9 & 28.9 & 12.5 & 8.8 & 9.0 & 12.8 & 8.3 & 2.8 & \\
\hline
\end{tabular}

1 NS-SEC assigned by the 'combined' method whereby if married the most advantaged class of either the woman or her husband is used to represent the woman's classification. Adjustments for the under-recording of death have been applied as described in Methods.

2 Younger age bands have been amalgamated where necessary due to avoid statistical disclosure issues.

3 Includes full-time students, never worked, long-term unemployed, inadequately described and not classified for other reasons. 


\section{Table A2}

Number of deaths by NS-SEC, ${ }^{1}$ cause $^{2}$ and age, women aged $25-59,2001-03$

continued

England and Wales

Numbers

\begin{tabular}{c|c|c|c|c|c|c|c|c|c|}
\hline & $\begin{array}{c}\text { Higher managerial } \\
\text { and professional }\end{array}$ & $\begin{array}{c}\text { Lower managerial } \\
\text { and professional }\end{array}$ & Intermediate & $\begin{array}{c}\text { Small employers } \\
\text { and own account } \\
\text { workers }\end{array}$ & $\begin{array}{c}\text { Lower supervisory } \\
\text { and technical }\end{array}$ & Semi-routine & Routine & Others ${ }^{3}$ & Total \\
\hline
\end{tabular}

Cancer of trachea, bronchus and lung

$\begin{array}{ccc}\text { Cancer of trachea, bronchus and lung } \\ 25-39 & 10 & \\ 40-44 & 24 & 137 \\ 45-49 & 67 & 326 \\ 50-54 & 121 & 462 \\ 55-59 & 182 & 1,003 \\ & 405 & 21.8 \\ \text { Total } & 8.8 & \end{array}$

$\begin{array}{rrr}22 & 11 & 8 \\ 55 & 29 & 23 \\ 137 & 69 & 72 \\ 326 & 155 & 145 \\ 462 & 232 & 255 \\ 1,003 & 496 & 503 \\ 21.8 & 10.8 & 10.9\end{array}$

$\begin{array}{rr}8 & 12 \\ 23 & 23 \\ 72 & 72 \\ 145 & 155 \\ 255 & 280 \\ 503 & 541 \\ 10.9 & 11.8\end{array}$

$\begin{array}{rr}12 & 14 \\ 23 & 45 \\ 72 & 130 \\ 155 & 229 \\ 280 & 420 \\ 541 & 838 \\ 11.8 & 18.2\end{array}$

$\begin{array}{rr}8 & 107 \\ 10 & 238 \\ 27 & 646 \\ 46 & 1,359 \\ 76 & 2,257 \\ 168 & 4,607 \\ 3.6 & \end{array}$

All circulatory diseases

$\begin{array}{lrr}\text { All circulatory diseases } & \\ 25-29 & 15 & 38 \\ 30-34 & 19 & 57 \\ 35-39 & 57 & 136 \\ 40-44 & 92 & 216 \\ 45-49 & 144 & 385 \\ 50-54 & 188 & 590 \\ 55-59 & 355 & 840 \\ & & \\ \text { Total } & 870 & 2,261 \\ \text { Percentage } & 7.6 & 19.7\end{array}$

$\begin{array}{rr}23 & 6 \\ 54 & 22 \\ 85 & 53 \\ 134 & 85 \\ 207 & 148 \\ 316 & 270 \\ 457 & 483 \\ 1,276 & 1,068 \\ 11.1 & 9.3\end{array}$

8
37
59
113
195
298
577
1,287
11.2

34
65
129
221
376
558
895
2,277
19.8

21
28
72
183
349
653
14.2

Ischaemic heart disease

\begin{tabular}{lrr}
\multicolumn{2}{l}{ Ischaemic heart disease } \\
$25-34$ & 4 & 13 \\
$35-39$ & 15 & 23 \\
$40-44$ & 26 & 54 \\
$45-49$ & 41 & 114 \\
$50-54$ & 66 & 220 \\
$55-59$ & 160 & 374 \\
Total & 311 & 798 \\
Percentage & 6.7 & 17.3
\end{tabular}

$\begin{array}{rr}7 & 3 \\ 21 & 17 \\ 42 & 19 \\ 70 & 54 \\ 120 & 103 \\ 217 & 213 \\ 477 & 409 \\ 10.3 & 8.9\end{array}$

$\begin{array}{rr}10 & 16 \\ 16 & 37 \\ 37 & 72 \\ 81 & 154 \\ 132 & 238 \\ 285 & 433 \\ 562 & 951 \\ 12.2 & 20.6\end{array}$

17
39
78
168
252
424
753
1,730
15.0

$\begin{array}{rr}22 & 162 \\ 39 & 333 \\ 65 & 663 \\ 83 & 1,111 \\ 119 & 1,826 \\ 171 & 2,816 \\ 235 & 4,594 \\ 735 & 11,505 \\ 6.4 & \end{array}$

Cerebrovascular disease

$\begin{array}{lrr}\text { Cerebrovascular disease } & \\ 25-29 & 5 & 9 \\ 30-34 & 5 & 27 \\ 35-39 & 20 & 57 \\ 40-44 & 38 & 89 \\ 45-49 & 56 & 168 \\ 50-54 & 73 & 201 \\ 55-59 & 106 & 239 \\ & & \\ \text { Total } & 303 & 789 \\ \text { Percentage } & 8.5 & 22.2\end{array}$

$\begin{array}{rr}10 & 3 \\ 23 & 7 \\ 31 & 18 \\ 46 & 32 \\ 71 & 49 \\ 104 & 94 \\ 129 & 152 \\ 413 & 355 \\ 11.6 & 10.0\end{array}$

3
13
18
41
61
92
155
383
10.8

806
$20.6-17.5$

10
21
65
112
203
394
806
17.5

$\begin{array}{rr}9 & 72 \\ 16 & 166 \\ 30 & 345 \\ 48 & 675 \\ 77 & 1,160 \\ 122 & 2,198 \\ 303 & 4,616 \\ 6.6 & \end{array}$

All respiratory diseases

\begin{tabular}{|c|c|c|c|c|c|c|c|c|c|}
\hline \multicolumn{10}{|c|}{ All respiratory diseases } \\
\hline $25-29$ & 3 & 10 & 16 & 5 & 5 & 20 & 9 & 11 & 79 \\
\hline $30-34$ & 9 & 19 & 16 & 11 & 16 & 30 & 15 & 16 & 132 \\
\hline $35-39$ & 13 & 30 & 20 & 10 & 18 & 37 & 26 & 28 & 183 \\
\hline $40-44$ & 21 & 58 & 30 & 23 & 33 & 64 & 45 & 29 & 303 \\
\hline $45-49$ & 24 & 64 & 50 & 42 & 41 & 97 & 74 & 50 & 443 \\
\hline $50-54$ & 65 & 159 & 88 & 74 & 123 & 198 & 185 & 76 & 968 \\
\hline $55-59$ & 91 & 281 & 172 & 139 & 224 & 354 & 309 & 115 & 1,686 \\
\hline Total & 226 & 621 & 393 & 306 & 460 & 800 & 663 & 325 & 3,794 \\
\hline Percentage & 6.0 & 16.4 & 10.3 & 8.1 & 12.1 & 21.1 & 17.5 & 8.6 & \\
\hline
\end{tabular}

All digestive diseases

\begin{tabular}{|c|c|c|c|c|c|c|c|c|c|}
\hline $25-29$ & 5 & 6 & 12 & 4 & 6 & 19 & 7 & 12 & 72 \\
\hline $30-34$ & 16 & 37 & 34 & 11 & 17 & 58 & 36 & 35 & 244 \\
\hline $35-39$ & 30 & 75 & 63 & 24 & 39 & 78 & 68 & 54 & 430 \\
\hline $40-44$ & 40 & 139 & 93 & 50 & 71 & 146 & 116 & 79 & 733 \\
\hline $45-49$ & 81 & 196 & 119 & 80 & 102 & 180 & 188 & 98 & 1,045 \\
\hline $50-54$ & 91 & 292 & 165 & 105 & 137 & 243 & 188 & 91 & 1,311 \\
\hline $55-59$ & 103 & 290 & 168 & 151 & 192 & 274 & 225 & 84 & 1,487 \\
\hline Total & 367 & 1,035 & 653 & 424 & 564 & 998 & 827 & 454 & 5,322 \\
\hline Percentage & 6.9 & 19.5 & 12.3 & 8.0 & 10.6 & 18.8 & 15.5 & 8.5 & \\
\hline
\end{tabular}

1 NS-SEC assigned by the 'combined' method whereby if married the most advantaged class of either the woman or her husband is used to represent the woman's classification. Adjustments for the under-recording of death have been applied as described in Methods.

2 Younger age bands have been amalgamated where necessary due to avoid statistical disclosure issues.

3 Includes full-time students, never worked, long-term unemployed, inadequately described and not classified for other reasons. 


\begin{tabular}{l|c|c|c|c|c|c|c|c|c|}
\hline & $\begin{array}{c}\text { Higher managerial } \\
\text { and professional }\end{array}$ & $\begin{array}{c}\text { Lower managerial } \\
\text { and professional }\end{array}$ & Intermediate & $\begin{array}{c}\text { Small employers } \\
\text { and own account } \\
\text { workers }\end{array}$ & $\begin{array}{c}\text { Lower supervisory } \\
\text { and technical }\end{array}$ & Semi-routine & Routine & Others ${ }^{3}$ \\
\hline
\end{tabular}

\section{North West}

$25-29$
$30-34$

$30-34$
$35-39$

40-44

$45-49$

50-54

55-59

Total

Percentage

North East

25-29

30-34

35-39

40-44

$45-49$
$50-54$

55-59

Total

Percentage

Yorkshire and The Humber

25-29

30-34

35-39

40-44

45-49

50-54

55-59

Total

Percentage

East Midlands

25-29

30-34

35-39

40-44

$45-49$
$50-54$

55-59

Total

Percentage

West Midlands

25-29

30-34

35-39

40-44

45-49

50-54

55-59

Total

Percentage

East of England

25-29

$30-34$

35-39

40-44

45-49

$50-54$

Total

Percentage

London

25-29 209

$\begin{array}{rrr}25-29 & 209 & 3 \\ 30-34 & 236 & 332 \\ 35-39 & 206 & 303 \\ 40-44 & 151 & 2 \\ 45-49 & 114 & 2 \\ 50-54 & 96 & 188 \\ 55-59 & 72 & 158 \\ \text { otal } & 1,084 & 1,777 \\ \text { Percentage } & 19.7 & 32.2\end{array}$

$\begin{array}{rr}170 & 109 \\ 209 & 116 \\ 227 & 115 \\ 214 & 103 \\ 195 & 89 \\ 188 & 93 \\ 157 & 87 \\ 1,361 & 712 \\ 28.2 & 14.8\end{array}$

$\begin{array}{rr}50 & \\ 61 & 5 \\ 62 & 42 \\ 54 & 34 \\ 47 & 27 \\ 53 & 22 \\ 58 & 19 \\ 384 & 18 \\ 8.0 & 218 \\ & 4.5\end{array}$

$\begin{array}{rr}55 & 611 \\ 42 & 749 \\ 34 & 798 \\ 27 & 733 \\ 22 & 650 \\ 19 & 666 \\ 18 & 612 \\ 218 & 4,819 \\ 4.5 & \end{array}$

$\begin{array}{rrrr}55 & 39 & 7 & 15 \\ 70 & 42 & 13 & 23 \\ 81 & 44 & 18 & 27 \\ 80 & 41 & 18 & 28 \\ 74 & 35 & 17 & 26 \\ 69 & 33 & 19 & 27 \\ 55 & 29 & 17 & 25 \\ 485 & 263 & 107 & 172 \\ 27.0 & 14.7 & 6.0 & 9.6\end{array}$

$\begin{array}{rr}15 & 39 \\ 23 & 48 \\ 27 & 50 \\ 28 & 45 \\ 26 & 36 \\ 27 & 39 \\ 25 & 36 \\ 172 & 293 \\ 9.6 & 16.3\end{array}$

$\begin{array}{rrr}21 & 21 & 218 \\ 27 & 16 & 270 \\ 29 & 13 & 300 \\ 26 & 11 & 287 \\ 23 & 9 & 253 \\ 25 & 8 & 249 \\ 26 & 8 & 218 \\ 178 & 85 & 1,795 \\ 9.9 & 4.7 & \end{array}$

150

150

156

142

138
112

983

983
27.5

75
79
78
72
62
66
62
494
13.8

$\begin{array}{rr}18 & 32 \\ 35 & 45 \\ 44 & 51 \\ 44 & 50 \\ 42 & 45 \\ 49 & 48 \\ 46 & 47 \\ 278 & 317 \\ 7.8 & 8.9\end{array}$

$\begin{array}{ll}44 & 38 \\ 53 & 28 \\ 52 & 21\end{array}$

$\begin{array}{ll}38 & 455 \\ 28 & 558 \\ 21 & 586 \\ 17 & 546\end{array}$

455
558

586
546

481

500

455

3,581

554

15.5

$\begin{array}{llll}57 & 35 & 26 & 374 \\ 70 & 45 & 20 & 478 \\ 70 & 44 & 16 & 504\end{array}$

504

465

418
435

413

3,087

857

27.8

413

13.4

134
163
171
160
148
140
125
1,041
27.5

$\begin{array}{rr}79 & 19 \\ 87 & 35 \\ 83 & 44 \\ 72 & 44 \\ 65 & 44 \\ 66 & 51 \\ 69 & 50 \\ 520 & 286 \\ 13.7 & 7.6\end{array}$

35

35
46
50
49

50
49
45

49
45
49

49
52

325
8.6

33
41
45
43
40
44
45
291
7.2

$\begin{array}{rr}78 & 4 \\ 94 & 5 \\ 93 & 48 \\ 82 & 42 \\ 72 & 38 \\ 77 & 43 \\ 86 & 5 \\ 581 & 31 \\ 15.4 & 8.3\end{array}$

479

591

614

561
509

517

512

3,781

$\begin{array}{rr}87 & \\ 92 & 20 \\ 88 & 39 \\ 80 & 52 \\ 75 & 52 \\ 84 & 50 \\ 83 & 61 \\ 588 & 59 \\ 14.6 & 334 \\ & 8.3\end{array}$

64
73
75
68
61
70
80
491
12.2

$\begin{array}{rr}33 & 28 \\ 37 & 21 \\ 36 & 17 \\ 30 & 13 \\ 27 & 11 \\ 32 & 9 \\ 37 & 10 \\ 233 & 110 \\ 5.8 & 2.7\end{array}$

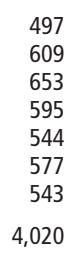

\begin{tabular}{|c|c|c|c|c|c|c|c|}
\hline 349 & 165 & 32 & 39 & 90 & 43 & 106 & 1,033 \\
\hline 332 & 153 & 51 & 41 & 96 & 44 & 72 & 1,026 \\
\hline 303 & 138 & 64 & 43 & 94 & 43 & 57 & 946 \\
\hline 243 & 114 & 61 & 40 & 84 & 37 & 41 & 771 \\
\hline 205 & 96 & 54 & 34 & 68 & 31 & 29 & 630 \\
\hline 88 & 95 & 54 & 33 & 67 & 31 & 21 & 585 \\
\hline 158 & 91 & 47 & 35 & 71 & 34 & 17 & 525 \\
\hline 777 & 852 & 363 & 263 & 571 & 263 & 342 & 5,516 \\
\hline 32.2 & 15.5 & 6.6 & 4.8 & 10.3 & 4.8 & 6.2 & \\
\hline
\end{tabular}

1 Population optimised for mortality analysis as described in Methods.

2 NS-SEC assigned by the 'combined' method whereby if married the most advantaged class of either the woman or her husband is used to represent the woman's classification. Adjustments for the under-recording of death have been applied as described in Methods.

3 Includes full-time students, never worked, long-term unemployed, inadequately described and not classified for other reasons. 


\section{Table A3}

continued

Population ${ }^{1}$ by NS-SEC ${ }^{2}$ and age, women aged $25-59,2001-03$

Government Office Regions of England, Wales

Thousands

\begin{tabular}{|c|c|c|c|c|c|c|c|c|c|}
\hline & $\begin{array}{c}\text { Higher managerial } \\
\text { and professional }\end{array}$ & $\begin{array}{l}\text { Lower managerial } \\
\text { and professional }\end{array}$ & Intermediate & $\begin{array}{c}\text { Small employers } \\
\text { and own account } \\
\text { workers } \\
\end{array}$ & $\begin{array}{c}\text { Lower supervisory } \\
\text { and technical }\end{array}$ & Semi-routine & Routine & Others ${ }^{3}$ & Total \\
\hline \multicolumn{10}{|l|}{ South East } \\
\hline $25-29$ & 126 & 239 & 124 & 28 & 44 & 84 & 45 & 43 & 734 \\
\hline $30-34$ & 207 & 287 & 132 & 55 & 55 & 94 & 45 & 30 & 905 \\
\hline $35-39$ & 243 & 309 & 129 & 75 & 61 & 97 & 47 & 25 & 986 \\
\hline $40-44$ & 222 & 288 & 116 & 75 & 58 & 88 & 40 & 19 & 906 \\
\hline $45-49$ & 188 & 265 & 108 & 72 & 52 & 78 & 34 & 15 & 810 \\
\hline $50-54$ & 174 & 268 & 123 & 85 & 57 & 89 & 37 & 13 & 847 \\
\hline $55-59$ & 137 & 238 & 124 & 83 & 60 & 102 & 45 & 13 & 802 \\
\hline Total & 1,298 & 1,894 & 856 & 474 & 386 & 632 & 292 & 158 & 5,989 \\
\hline Percentage & 21.7 & 31.6 & 14.3 & 7.9 & 6.5 & 10.6 & 4.9 & 2.6 & \\
\hline \multicolumn{10}{|l|}{ South West } \\
\hline $25-29$ & 51 & 126 & 68 & 18 & 32 & 62 & 31 & 25 & 413 \\
\hline $30-34$ & 84 & 161 & 75 & 38 & 41 & 71 & 36 & 19 & 526 \\
\hline $35-39$ & 101 & 175 & 74 & 50 & 45 & 73 & 35 & 16 & 570 \\
\hline $40-44$ & 98 & 168 & 68 & 53 & 42 & 67 & 30 & 12 & 539 \\
\hline $45-49$ & 86 & 159 & 65 & 54 & 38 & 60 & 26 & 10 & 500 \\
\hline $50-54$ & 84 & 162 & 72 & 67 & 41 & 68 & 30 & 9 & 532 \\
\hline $55-59$ & 68 & 144 & 71 & 68 & 42 & 78 & 36 & 10 & 518 \\
\hline Total & 573 & 1,096 & 494 & 348 & 283 & 480 & 224 & 101 & 3,598 \\
\hline Percentage & 15.9 & 30.5 & 13.7 & 9.7 & 7.9 & 13.3 & 6.2 & 2.8 & \\
\hline \multicolumn{10}{|l|}{ Wales } \\
\hline $25-29$ & 23 & 67 & 40 & 9 & 19 & 41 & 22 & 22 & 245 \\
\hline $30-34$ & 37 & 85 & 43 & 19 & 27 & 49 & 27 & 17 & 303 \\
\hline $35-39$ & 44 & 93 & 42 & 25 & 30 & 50 & 28 & 14 & 326 \\
\hline $40-44$ & 42 & 92 & 39 & 26 & 29 & 45 & 23 & 11 & 307 \\
\hline $45-49$ & 39 & 86 & 35 & 27 & 26 & 39 & 21 & 10 & 282 \\
\hline $50-54$ & 38 & 85 & 35 & 33 & 28 & 41 & 24 & 9 & 295 \\
\hline $55-59$ & 31 & 73 & 33 & 32 & 28 & 43 & 25 & 10 & 275 \\
\hline Total & 254 & 581 & 267 & 172 & 187 & 308 & 171 & 93 & 2,033 \\
\hline Percentage & 12.5 & 28.6 & 13.1 & 8.5 & 9.2 & 15.2 & 8.4 & 4.6 & \\
\hline
\end{tabular}

1 Population optimised for mortality analysis as described in Methods.

2 NS-SEC assigned by the 'combined' method whereby if married the most advantaged class of either the woman or her husband is used to represent the woman's classification. Adjustments for the under-recording of death have been applied as described in Methods.

3 Includes full-time students, never worked, long-term unemployed, inadequately described and not classified for other reasons. 


\section{Appendix B}

Table B1

Age Standardised mortality rates ${ }^{1}$ by NS-SEC ${ }^{2}$ without adjustments for under-recording of occupation at death, women aged 25-59, 2001-03
Rate per 100,000

Government Office Regions of England, Wales

\begin{tabular}{|c|c|c|c|c|c|c|c|c|c|}
\hline & \multicolumn{7}{|c|}{ NS-SEC analytic class } & \multicolumn{2}{|c|}{ Socio-economic gradient $^{3}$} \\
\hline & 1 & 2 & 3 & 4 & 5 & 6 & 7 & $\begin{array}{c}\text { Without } \\
\text { adjustments }\end{array}$ & $\begin{array}{c}\text { With } \\
\text { adjustment }\end{array}$ \\
\hline North East & 112 & $\begin{array}{r}139 \\
H\end{array}$ & 133 & 171 & $\begin{array}{r}200 \\
H\end{array}$ & 183 & $\begin{array}{r}271 \\
H\end{array}$ & 2.4 & 2.6 \\
\hline North West & 112 & $\begin{array}{r}143 \\
H\end{array}$ & $\begin{array}{r}136 \\
H\end{array}$ & $\begin{array}{r}171 \\
H\end{array}$ & $\begin{array}{r}200 \\
H\end{array}$ & $\begin{array}{r}201 \\
H\end{array}$ & $\begin{array}{r}294 \\
H\end{array}$ & 2.6 & 3.0 \\
\hline Yorkshire and The Humber & 109 & 128 & 117 & 155 & 163 & 168 & 238 & 2.2 & 2.4 \\
\hline East Midlands & 113 & 133 & 117 & 154 & $\begin{array}{r}155 \\
\text { L }\end{array}$ & 169 & $\begin{array}{r}215 \\
\text { L }\end{array}$ & 1.9 & 2.1 \\
\hline West Midlands & 109 & 127 & $\begin{array}{r}114 \\
\text { L }\end{array}$ & 147 & 188 & 177 & 240 & 2.2 & 2.5 \\
\hline East of England & 113 & $\begin{array}{r}116 \\
\mathrm{~L}\end{array}$ & 123 & 139 & $\begin{array}{r}150 \\
\mathrm{~L}\end{array}$ & 163 & $\begin{array}{r}194 \\
\text { L }\end{array}$ & 1.7 & 2.1 \\
\hline London & 105 & 122 & $\begin{array}{r}135 \\
H\end{array}$ & $\begin{array}{r}164 \\
H\end{array}$ & 168 & $\begin{array}{r}185 \\
H\end{array}$ & 233 & 2.2 & 3.0 \\
\hline South East & 107 & $\begin{array}{r}121 \\
\mathrm{~L}\end{array}$ & 118 & $\begin{array}{r}120 \\
L\end{array}$ & 170 & $\begin{array}{r}153 \\
L\end{array}$ & $\begin{array}{r}208 \\
\text { L }\end{array}$ & 2.0 & 2.5 \\
\hline South West & 106 & $\begin{array}{r}120 \\
\mathrm{~L}\end{array}$ & $\begin{array}{r}110 \\
\mathrm{~L}\end{array}$ & $\begin{array}{r}133 \\
L\end{array}$ & 165 & $\begin{array}{r}150 \\
\mathrm{~L}\end{array}$ & $\begin{array}{r}206 \\
L\end{array}$ & 1.9 & 2.4 \\
\hline Wales & 115 & 136 & 136 & 160 & 183 & 162 & $\begin{array}{r}276 \\
H\end{array}$ & 2.4 & 2.7 \\
\hline England and Wales & 110 & 128 & 124 & 148 & 175 & 172 & 239 & 2.2 & 2.6 \\
\hline
\end{tabular}

1 Directly standardised rate using the European standard population.

2 NS-SEC assigned by the 'combined' method whereby if married the most advantaged class of either the woman or her husband is used to represent the woman's classification. Adjustments for the under-recording of death have NOT been applied as described in Methods.

3 Ratio of mortality rates of NS-SEC class 7 to the mortality rate of NS-SEC class 1.

H Rate is statistically significantly higher than that for England and Wales. Rate is statistically significantly lower than that for England and Wales.

\section{Table B2}

England and Wales

\section{Age-standardised mortality rates ${ }^{1}$ from selected malignant neoplasms by NS-SEC, ${ }^{2}$ women aged $25-59,2001-03$}

\begin{tabular}{|c|c|c|c|c|c|c|c|c|}
\multicolumn{2}{|c|}{ Rate per 100,000 } \\
\hline Rate
\end{tabular}

1 Higher managerial and professional

NS-SEC analytic class

2 Lower managerial and professional

$71 \quad 75$

75

3 Intermediate

4 Small employers and own account workers

5 Lower supervisory and technical

6 Semi-routine

7 Routine

73

73

63

75
66

66
82

$82 \quad 79$

77

98

89

75

95

$1.4 \quad 1.3$

76

68

85

96

80

102

1.4

6

726

$25-27$

1 Directly age-standardised using European standard population.

2 NS-SEC assigned by the 'combined' method whereby if married the most advantaged class of either the woman or her husband is used to represent the woman's classification. Adjustments for the under-recording of death have NOT been applied. 


\begin{tabular}{|c|c|c|c|c|c|c|c|c|c|}
\hline \multirow[b]{2}{*}{ NS-SEC analytic class } & \multicolumn{3}{|c|}{ All circulatory diseases } & \multicolumn{3}{|c|}{ Ischaemic heart disease } & \multicolumn{3}{|c|}{ Cerebrovascular diseases } \\
\hline & Rate & $\begin{array}{c}\text { Lower } 95 \% \\
\text { confidence } \\
\text { interval }\end{array}$ & $\begin{array}{c}\text { Upper } 95 \% \\
\text { confidence } \\
\text { interval }\end{array}$ & Rate & $\begin{array}{c}\text { Lower } 95 \% \\
\text { confidence } \\
\text { interval }\end{array}$ & $\begin{array}{c}\text { Upper } 95 \% \\
\text { confidence } \\
\text { interval }\end{array}$ & Rate & $\begin{array}{c}\text { Lower } 95 \% \\
\text { confidence } \\
\text { interval }\end{array}$ & $\begin{array}{c}\text { Upper } 95 \% \\
\text { confidence } \\
\text { interval }\end{array}$ \\
\hline
\end{tabular}

1 Higher managerial and professional

2 Lower managerial and professional

3 Intermediate

4 Small employers and own account workers

5 Lower supervisory and technica

6 Semi-routine

7 Routine

$\begin{array}{lll}13 & 12 & 14 \\ 19 & 18 & 20 \\ 19 & 18 & 20 \\ 27 & 25 & 28 \\ 34 & 32 & 36 \\ 35 & 34 & 37 \\ 51 & 48 & 54 \\ 3.8 & 3.5 & 4.1\end{array}$

5

4

Ratio 7:1

7

7

10

15
15

15

24

1 Directly age-standardised using European standard population.

2 NS-SEC assigned by the 'combined' method whereby if married the most advantaged class of either the woman or her husband is used to represent the woman's classification. Adjustments for the under-recording of death have NOT been applied.

\section{Table B4}

England and Wales

Age-standardised mortality rates ${ }^{1}$ from all respiratory and all digestive diseases by NS-SEC, ${ }^{2}$ women aged 25-59, 2001-03

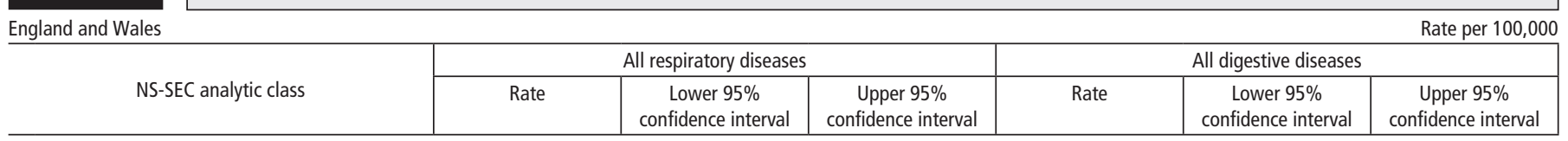

\footnotetext{
1 Higher managerial and professional

2 Lower managerial and professional

3 Intermediate

4 Small employers and own account workers

5 Lower supervisory and technical

6 Semi-routine

7 Routine
}

Ratio 7:1

1 Directly age-standardised using European standard population.

2 NS-SEC assigned by the 'combined' method whereby if married the most advantaged class of either the woman or her husband is used to represent the woman's classification. Adjustments for the under-recording of death have NOT been applied.
Age-standardised mortality rates ${ }^{1}$ for selected causes and regions by NS-SEC, ${ }^{2}$ women aged $25-59$, 2001-03

Rate per 100,000

\begin{tabular}{c|c|c|c|c|}
\hline \multirow{2}{*}{ NS-SEC analytic class } & \multicolumn{3}{|c}{ Rate per 100,000 } \\
\cline { 2 - 5 } & $\begin{array}{c}\text { North } \\
\text { West }\end{array}$ & $\begin{array}{c}\text { South } \\
\text { West }\end{array}$ & $\begin{array}{c}\text { North } \\
\text { West }\end{array}$ & $\begin{array}{c}\text { South } \\
\text { West }\end{array}$ \\
\hline
\end{tabular}

1 Higher managerial and professional

2 Lower managerial and professional

3 Intermediate

4 Small employers and own account workers

5 Lower supervisory and technical

6 Semi-routine

7 Routine

$\begin{array}{llll}66 & 74 & 15 & 10\end{array}$

Ratio 7:1

$82 \quad 72$

$68 \quad 59$

$\begin{array}{ll}68 & 59 \\ 91 & 80\end{array}$

$95 \quad 90$

$88 \quad 67$

$105 \quad 96$

$1.6 \quad 1.3$

1 Directly age-standardised using European standard population.

2 NS-SEC assigned by the 'combined' method whereby if married the most advantaged class of either the woman or her husband is used to represent the woman's classification. Adjustments for the under-recording of death have NOT been applied. 